\title{
Global Pattern of Gene Expression of Xanthomonas axonopodis pv. glycines Within Soybean Leaves
}

\author{
Tiyakhon Chatnaparat, ${ }^{1,2}$ Sutruedee Prathuangwong, ${ }^{1,2}$ and Steven E. Lindow ${ }^{3}$ \\ ${ }^{1}$ Department of Plant Pathology, Kasetsart University, Thailand; ${ }^{2}$ Center for Advanced Studies in Tropical Natural Resources, \\ Kasetsart University, Bangkok, Thailand; and ${ }^{3}$ Department of Plant and Microbial Biology, University of California, Berkeley, \\ CA 94720 , U.S.A.
}

Submitted 10 January 2016. Accepted 16 March 2016.

\begin{abstract}
To better understand the behavior of Xanthomonas axonopodis pv. glycines, the causal agent of bacterial pustule of soybean within its host, its global transcriptome within soybean leaves was compared with that in a minimal medium in vitro, using deep sequencing of mRNA. Of 5,062 genes predicted from a draft genome of $X$. axonopodis pv. glycines, 534 were upregulated in the plant, while 289 were down-regulated. Genes encoding YapH, a cell-surface adhesin, as well as several others encoding cell-surface proteins, were down-regulated in soybean. Many genes encoding the type III secretion system and effector proteins, cell wall-degrading enzymes and phosphate transporter proteins were strongly expressed at early stages of infection. Several genes encoding RND multidrug efflux pumps were induced in planta and by isoflavonoids in vitro and were required for full virulence of $X$. axonopodis pv. glycines, as well as resistance to soybean phytoalexins. Genes encoding consumption of malonate, a compound abundant in soybean, were induced in planta and by malonate in vitro. Disruption of the malonate decarboxylase operon blocked growth in minimal media with malonate as the sole carbon source but did not significantly alter growth in soybean, apparently because genes for sucrose and fructose uptake were also induced in planta. Many genes involved in phosphate metabolism and uptake were induced in planta. While disruption of genes encoding high-affinity phosphate transport did not alter growth in media varying in phosphate concentration, the mutants were severely attenuated for growth in soybean. This global transcriptional profiling has provided insight into both the intercellular environment of this soybean pathogen and traits used by $X$. axonopodis pv. glycines to promote disease.
\end{abstract}

Xanthomonas axonopodis pv. glycines is a foliar pathogen causing bacterial pustule disease, one of the most serious diseases of soybean. Disease symptoms include numerous small pustules, formed by hypertrophy and hyperplasia of parenchyma cells (Groth and Braun 1986), surrounded by chlorotic halos on leaves. Like other foliar pathogens, X. axonopodis pv. glycines presumably persists as an epiphyte on the surface of healthy plants before entering the intercellular spaces (apoplast) of soybean via natural openings such as stomata or wounds. Once in the apoplast,

Corresponding author: S. Prathuangwong; E-mail: agrsdp@ku.ac.th

*The $\boldsymbol{e}$-Xtra logo stands for "electronic extra" and indicates that two supplementary figures and two supplementary tables are published online.

(c) 2016 The American Phytopathological Society in which they obtain sufficient nutrients to multiply to high population sizes, they incite disease symptoms (Jones and Fett 1985).

Several virulence factors have been described in $X$. axonopodis pv. glycines, including the exoenzymes cellulase, protease, endo- $\beta$-1,4-mannanase, and pectate lyases as well as the secreted virulence factors indole acetic acid and cytokinin (Hokawat and Rudolph 1993; Kaewnum et al. 2006; Thowthampitak et al. 2008). Like that of many other plant pathogens, $X$. axonopodis pv. glycines uses a type III secretion system (T3SS) to secrete effectors such as $a v r X g 1$ into the host cell (Athinuwat et al. 2009; Kim et al. 2003). X. axonopodis pv. glycines also employs several different global regulators to coordinate expression of target genes in a context-dependent manner. Cell density-dependent behaviors are coordinated by a diffusible signal factor-dependent quorum sensing system encoded by the rpf locus (Thowthampitak et al. 2008). In addition, a novel LuxR homolog, XagR, was recently shown to differentially affect expression of pip, yapH, and at least 77 other genes during the infection event, in response to feedback from plant molecules (Chatnaparat et al. 2012). While certain virulence genes of $X$. axonopodis pv. glycines have been previously identified, little information is available on their patterns of expression during interaction with the plant.

A variety of methods have been used recently to identify genes in several different plant-pathogenic bacteria that are upregulated in planta. In vivo expression technology (IVET) was performed to identify genes of Pseudomonas syringae pv. tomato, Erwinia chrysanthemi, Erwinia amylovora, Ralstonia solanacearum, and Xanthomonas campestris pv. campestris that are up-regulated in their plant host during the infection process (Boch et al. 2002; Brown and Allen 2004; Osbourn et al. 1987; Yang et al. 2004; Zhao et al. 2005). Likewise, a recombinase-based in vivo expression technology was used to identify genes in $X$. campestris pv. vesicatoria upregulated during its interaction with tomato (Tamir-Ariel et al. 2007). A variant of the IVET system termed habitat-inducible rescue of survival was used to identify some plant-induced genes in P. syringae pv. syringae (Marco et al. 2005). While these methods have provided insight into environmentally induced changes in gene expression of several plant-pathogenic bacteria, most provide an incomplete inventory of gene expression, restricted to those genes that are relatively highly expressed, and can identify only those genes that show upregulation (but not downregulation). DNA microarray-based techniques have, thus, been used more recently to study global gene expression patterns of Ralstonia solanacearum, P. syringae pv. syringae, and X. oryzae pv. oryzae in planta (Jacobs et al. 2012; SotoSuárez et al. 2010; Yu et al. 2013) but still suffer somewhat 
from lack of sensitivity for transcripts that are of low abundance. Global transcriptome analysis using direct mRNA sequencing (RNA-Seq) can achieve unprecedented levels of accuracy and specificity in quantifying gene expression. Moreover, RNA-Seq does not depend on genome annotation for prior probe selection and avoids the related biases introduced during hybridization of microarrays. While RNA-Seq has proven to be a powerful technique used to characterize expression of all the genes from several plant-pathogenic bacteria under in vitro conditions (Hockett et al. 2013; Liu et al. 2013), it has received little application for studies in planta because of the need to selectively isolate transcripts of the pathogen relative to that of host RNA so that sufficient cDNA sequences could be obtained to enable accurate estimates of the abundance of pathogen transcripts.

To better understand the behavior of $X$. axonopodis pv. glycines within soybean, its global transcriptome was assessed, using deep sequencing of mRNA. Methodologies for selective recovery of pathogen transcripts were developed that enabled accurate estimates of the abundance of even relatively rare transcripts to be assessed. The patterns of expression of a variety of genes provided insight into the apoplastic environment of soybean pathogen and the contribution of some of the plant-inducible genes of $X$. axonopodis pv. glycines to its virulence were demonstrated.

\section{RESULTS}

\section{Transcripts of $X$. axonopodis pv. glycines 12-2 in soybean leaves.}

To identify genes of $X$. axonopodis pv. glycines that were either up- or down-regulated during its interaction with soybean, the global transcriptome of $X$. axonopodis pv. glycines within soybean leaves was compared with that in a minimal medium in vitro, using RNA sequencing. X. axonopodis pv. glycines $12-2$ was inoculated into soybean and was subsequently collected after 3 days, while cells grown in M9 minimal medium were harvested at mid-exponential phase (optical desnity at $600 \mathrm{~nm}$ $\left[\mathrm{OD}_{600}\right]=0.6$ ). Sequencing of three replicate cDNA samples of $X$. axonopodis pv. glycines recovered from soybean yielded 40.6, 60.1 , and 77.6 million reads and 57.76, 60.24, and 57.19\% of the sequence reads could be aligned to open reading frames present in the $X$. axonopodis pv. glycines draft genome. Of the 5,062 genes of $X$. axonopodis pv. glycines, 823 were significantly differentially expressed and by at least fourfold when compared with that when grown in M9 minimal medium. Of these, 534 were up-regulated in the plant while 289 were down-regulated (Supplementary Table S1).

To confirm the differential expression of these genes, quantitative reverse transcription-polymerase chain reaction (qRTPCR) analysis was carried out on aliquots of the same RNA samples used in RNA-Seq. Ten selected genes exhibited the same relative gene expression as that found during RNA-Seq analysis, with a Spearman's rank correlation coefficient $(R)$ at 0.8061 (Supplementary Fig. S1).

\section{Annotation of genes differentially expressed in planta.}

Given that a large number of $X$. axonopodis pv. glycines genes were up-regulated within the apoplast of soybean relative to that in a minimal medium, a thorough annotation of these genes was performed to ascertain those that could most directly be linked to the virulence of this pathogen. Several different virulence genes, including the hrp cluster encoding machinery for the T3SS, putative effectors delivered by the T3SS, and host cell wall-degrading enzymes (CWDE) were strongly up-regulated. Among the differentially regulated genes of $X$. axonopodis pv. glycines, several known as well as novel putative virulence factors related to that in other Xanthomonas spp. or other pathogens were up-regulated in soybean (Table 1). These included the regulators $h r p G$ and $h r p X$ (XagID1272-1273), which encodes an important regulatory protein of the $h r p$ cluster (XagID415-440), and genes encoding avirulence and type III effector proteins, such as an avirulence protein that is homologous to those in the AvrBs3/pthA family, and the putative type III effector HolPtoQ. In addition to the genes encoding Hrp/T3SS, other pathogenicity genes linked to the type II secretion system (T2SS) were also found to be up-regulated in soybean. The genes encoding various CWDE, including polygalacturonase (PG) (XagID691, XagID2260), xylanase (XagID972), xylanase precursor (XagID4015), and xylosidase/arabinosidase (XagID2392) were expressed at a higher level in planta. Such plant CWDE are secreted by the T2SS (Ryan et al. 2011).

Several genes encoding multidrug efflux pumps were upregulated in $X$. axonopodis pv. glycines within the apoplast. Efflux pumps are part of a complex system important in the processes by which toxic compounds are tolerated as well as in trafficking small molecules involved in interactions with hosts, cell homeostasis, intercellular signaling, and virulence (Burse et al. 2004; Maggiorani Valecillos et al. 2006; Martinez et al. 2009; Piddock 2006; Ravirala et al. 2007; Vargas et al. 2011). Several $X$. axonopodis pv. glycines genes encoding multidrug efflux pumps were strongly induced in planta. For example, three operons encoding RND (resistance-nodulation-division) multidrug efflux pumps (XagID2687-2689, XagID342-343, and XagID1501-1504) were expressed more than fourfold higher in the soybean apoplast compared with that in minimal medium. In addition, genes predicted to encode other multidrug resistance systems (XagID1460-1462 and XagID2334-2336) were both much more highly expressed in soybean than in vitro.

Several genes in $X$. axonopodis pv. glycines that enable it to utilize carbon resources in soybean were up-regulated in the apoplast. Such genes included those encoding a $\mathrm{Mg}^{++} /$citrate complex transporter (XagID3278), succinate-semialdehyde dehydrogenase (XagID2330), the fructose-specific IIB component of the phosphotransferase transporter carbohydrate transport system (XagID2367), endoglucanase precursor protein (XagID3305), gluconolactonase (XagID577), 2-dehydro3-deoxygalactonokinase (XagID1758), glucoamylase (XagID3038), and malate synthase (XagID269). Perhaps most noteworthy was the finding that genes in the operon encoding malonate decarboxylase (XagID590-596) enabling consumption of malonate, a compound particularly abundant in soybean, were strongly induced in planta.

A variety of genes involved in phosphorous metabolism were up-regulated in X. axonopodis pv. glycines in the apoplast. Several genes in $X$. axonopodis pv. glycines involved in phosphate transport, including those encoding the PhoR-PhoB two component system (XagID1081-1082) that regulate the phosphate-specific transport (Pst) system (pstSCAB-phoU operon) (XagID15771583 ) were significantly induced in soybean. In addition, the gene encoding a putative phytase precursor (XagID2378) was also up-regulated in soybean. It has been reported that phyA, a gene encoding phytase A of $X$. oryzae pv. oryzae is involved in promoting utilization of phytic acid as a phosphate source and contributes to its virulence in rice (Chatterjee et al. 2003). $X$. axonopodis pv. glycines, thus, apparently also perceives low phosphate conditions in the apoplast, necessitating the scavenging of phosphate from phytic acid.

Several genes involved in the putative response of $X$. axonopodis pv. glycines to chemical stresses were induced in the apoplast, suggesting that it experiences these conditions during the infection process. During the infection process, reactive oxygen species are often produced in plants that can cause substantial damage to all cellular components of the pathogen as a defense against pathogen attack. Peroxiredoxins and bacterioferritin are a family of antioxidant proteins ubiquitously conserved in a wide 
Table 1. Differential expression of genes in Xanthomonas axonopodis pv. glycines 12-2 during growth in soybean

\begin{tabular}{|c|c|c|c|}
\hline \multirow[b]{2}{*}{ GeneID } & \multirow[b]{2}{*}{ Function } & \multicolumn{2}{|c|}{ Ratio (plant/M9) } \\
\hline & & Fold change $\left(\log _{2}\right)$ & $P$ value \\
\hline \multicolumn{4}{|c|}{ TypeIII secretion system (T3SS) } \\
\hline Xag 1272 & HrpG protein & 1.07 & 0 \\
\hline Xag1273 & HrpX protein & 3.79 & 0 \\
\hline Xag415 & HpaF protein & 2.63 & 0 \\
\hline Xag416 & HrpF protein & 4.70 & 0 \\
\hline Xag417 & FIG01211675; hypothetical protein & 1.15 & $2.49 \mathrm{E}-40$ \\
\hline Xag418 & Type III effector & 0.14 & 0.019568 \\
\hline Xag419 & HpaB protein & 5.07 & 0 \\
\hline Xag420 & HrpE protein & 3.08 & 0 \\
\hline Xag421 & HrpD6 protein & 5.58 & 0 \\
\hline Xag422 & HrpD5 protein & 6.15 & 0 \\
\hline Xag423 & HpaA protein & 4.28 & 0 \\
\hline Xag424 & $\begin{array}{l}\text { Type III secretion (T3SS) inner membrane protein (YscS, homologous } \\
\text { to flagellar export components) }\end{array}$ & 4.81 & 0 \\
\hline Xag425 & $\begin{array}{l}\text { T3SS inner membrane protein (YscR, SpaR, HrcR, EscR, homologous } \\
\text { to flagellar export components) }\end{array}$ & 3.98 & 0 \\
\hline Xag426 & HrcQ protein & 5.20 & 0 \\
\hline Xag427 & $\mathrm{HpaP}$ protein & 5.63 & 0 \\
\hline Xag428 & T3SS inner membrane channel protein (LcrD, HrcV, EscV, SsaV) & 3.83 & 0 \\
\hline Xag429 & $\begin{array}{l}\text { T3SS inner membrane protein (YscU, SpaS, EscU, HrcU, SsaU, } \\
\text { homologous to flagellar export components) }\end{array}$ & 4.95 & 0 \\
\hline Xag430 & HrpB1 protein & 7.40 & 0 \\
\hline Xag431 & HrpB2 protein & 6.20 & 0 \\
\hline Xag432 & $\begin{array}{l}\text { T3SS bridge between inner and outermembrane lipoprotein } \\
\text { (YscJ, HrcJ, EscJ, PscJ) }\end{array}$ & 5.61 & 0 \\
\hline Xag433 & HrpB4 protein & 5.74 & 0 \\
\hline Xag434 & T3SS inner membrane protein SctL & 5.97 & 0 \\
\hline Xag435 & $\begin{array}{l}\text { T3SS cytoplasmic ATP synthase (EC 3.6.3.14, YscN, SpaL, MxiB, } \\
\text { HrcN, EscN) }\end{array}$ & 5.21 & 0 \\
\hline Xag436 & HrpB7 protein & 4.02 & 0 \\
\hline Xag437 & $\begin{array}{l}\text { T3SS inner membrane protein (YscT, HrcT, SpaR, EscT, EpaR1, } \\
\text { homologous to flagellar export components) }\end{array}$ & 4.32 & 0 \\
\hline Xag438 & T3SS outermembrane pore forming protein (YscC, MxiD, HrcC, InvG) & 4.14 & 0 \\
\hline Xag439 & Hpa1 protein & 6.73 & 0 \\
\hline Xag440 & $\mathrm{Hpa} 2$ protein & 3.19 & 0 \\
\hline Xag4086 & Candidate type III effector HolPtoQ & 2.26 & 0 \\
\hline Xag(1)_100 & Candidate type III effector HolPtoQ & 4.74 & 0 \\
\hline Xag301 & Avirulence protein & 3.35 & 0 \\
\hline Xag3053 & Avirulence protein & 2.25 & 0 \\
\hline Xag(1)_26 & Avirulence protein & 5.26 & 0 \\
\hline Xag(1)_411 & Avirulence protein & 1.22 & 0 \\
\hline Xag(1)_59 & Avirulence protein & 2.49 & 0 \\
\hline Xag(1)_862 & Avirulence protein & 0.37 & $1.00 \mathrm{E}-22$ \\
\hline \multicolumn{4}{|c|}{ Multidrug resistance efflux pumps } \\
\hline Xag1501 & RND efflux system, membrane fusion protein CmeA & 2.71 & 0 \\
\hline Xag1502 & RND efflux system, inner membrane transporter CmeB & 2.41 & 0 \\
\hline Xag1504 & RND efflux system, outer membrane lipoprotein CmeC & 1.66 & 0 \\
\hline Xag2361 & RND efflux system, membrane fusion protein CmeA & 1.44 & 0 \\
\hline Xag2362 & RND efflux system, inner membrane transporter CmeB & 0.41 & $6.21 \mathrm{E}-83$ \\
\hline Xag2644 & Acriflavin resistance protein & -0.52 & $1.25 \mathrm{E}-06$ \\
\hline Xag2687 & RND efflux system, outer membrane lipoprotein CmeC & 5.79 & 0 \\
\hline Xag2688 & RND efflux system, inner membrane transporter CmeB & 6.76 & 0 \\
\hline Xag2689 & RND efflux system, membrane fusion protein CmeA & 8.21 & 0 \\
\hline Xag2690 & Transcription regulator of multidrug efflux pump operon, TetR (AcrR) family & 0.37 & $1.90 \mathrm{E}-24$ \\
\hline Xag3116 & RND multidrug efflux transporter; Acriflavin resistance protein & -0.99 & $1.98 \mathrm{E}-208$ \\
\hline Xag3117 & Membrane fusion protein of RND family multidrug efflux pump & -0.75 & $1.19 \mathrm{E}-117$ \\
\hline Xag342 & RND efflux system, membrane fusion protein $\mathrm{CmeA}$ & 3.30 & 0 \\
\hline Xag343 & RND efflux system, inner membrane transporter CmeB & 1.82 & $1.32 \mathrm{E}-168$ \\
\hline Xag3738 & Acriflavin resistance protein & -1.05 & $5.90 \mathrm{E}-226$ \\
\hline Xag(1)_186 & Acriflavin resistance protein & -0.31 & 4.36E-98 \\
\hline Xag(1)_817 & RND efflux system, membrane fusion protein CmeA & 1.38 & $1.25 \mathrm{E}-59$ \\
\hline Xag(1)_822 & RND efflux system, inner membrane transporter CmeB & 1.89 & 0 \\
\hline Xag(1)_914 & RND efflux system, outer membrane lipoprotein CmeC & 5.75 & 0 \\
\hline \multicolumn{4}{|c|}{ Multidrug resistance, tripartite systems } \\
\hline Xag1460 & Outer membrane component of tripartite multidrug resistance system & 1.85 & 0 \\
\hline Xag1461 & Membrane fusion component of tripartite multidrug resistance system & 2.14 & 0 \\
\hline Xag1462 & Inner membrane component of tripartite multidrug resistance system & 0.66 & 7.40E-98 \\
\hline Xag2334 & Outer membrane component of tripartite multidrug resistance system & 2.85 & 0 \\
\hline Xag2335 & Inner membrane component of tripartite multidrug resistance system & 2.09 & 0 \\
\hline \multirow[t]{2}{*}{ Xag2336 } & Membrane fusion component of tripartite multidrug resistance system & 2.30 & 0 \\
\hline & & \multicolumn{2}{|c|}{ (continued on next page) } \\
\hline
\end{tabular}


Table 1. (continued from previous page)

Ratio (plant/M9)

GeneID

Function

Fold change $\left(\log _{2}\right)$

$P$ value

Carbon metabolism

Malonate decarboxylase

Xag590

Xag591

Xag592

Xag593

Xag594

Xag595

Xag596

Fructose utilization

Xag2365

Xag2366

Xag2812

Xag2367

Xag939

Methylcitrate cycle

Xag1144

Xag1145

Xag1146

Xag1147

D-Galactur

Xag 170

Xag 171

Xag2260

Xag3355

Xag351

Xag4014

Xag4018

Xag691

Xag150

Xag2056

Xag2462

Xag2407

Xag4011

Xag1758

Xag1760

Xylose utilization

Xag1283

Xag168

Xag1770

Xag1771

Xag1772

Xag3800

Xag3935

Xag3988

Xag3993

Xag972

Xag973

High affinity phosphate transporter and control of $\mathrm{PHO}$ regulon

Xag1081

Xag1082

Xag1583

Xag1577

Xag1578

Xag1579

Xag1580

Xag1079

Choline and

Xag184

Xag185

Xag749

Xag750

Xag751

Flagellar motility

Xag1904

Xag1905

Xylanase

PstS (TC 3.A.1.7.1)

(TC 3.A.1.12.1)
Malonate decarboxylase $\alpha$ subunit

Malonate decarboxylase delta subunit

Malonate decarboxylase $\beta$ subunit

Malonate decarboxylase $\gamma$ subunit

Phosphoribosyl-dephospho-CoA transferase (EC 2.7.7.-)

Triphosphoribosyl-dephospho-CoA synthetase (EC 2.7.8.25)

Malonyl CoA acyl carrier protein transacylase (EC 2.3.1.39)

Phosphoenolpyruvate-protein phosphotransferase of the

phosphotransferase transporter system (PTS) (EC 2.7.3.9)

1-phosphofructokinase (EC 2.7.1.56)

Phosphoenolpyruvate-protein phosphotransferase of the PTS (EC 2.7.3.9)

PTS system, fructose-specific IIB component (EC 2.7.1.69)/PTS,

fructose-specific IIC component (EC 2.7.1.69)

Transaldolase (EC 2.2.1.2)

Propionate catabolism operon regulatory protein PrpR

Methylisocitrate lyase (EC 4.1.3.30)

2-Methylcitrate synthase (EC 2.3.3.5)

2-Methylcitrate dehydratase FeS dependent (EC 4.2.1.79)

4-Deoxy-L-threo-5-hexosulose-uronate ketol-isomerase (EC 5.3.1.17)

2-deoxy-D-gluconate 3-dehydrogenase (EC 1.1.1.125)

Polygalacturonase (EC 3.2.1.15)

Pectate lyase precursor (EC 4.2.2.2)

2-Keto-3-deoxygluconate permease

Uronate isomerase (EC 5.3.1.12)

Hexuronate transporter

Polygalacturonase (EC 3.2.1.15)

2-Dehydro-3-deoxygluconate kinase (EC 2.7.1.45)

4-Hydroxy-2-oxoglutarate aldolase (EC 4.1.3.16)/2-dehydro-3-

deoxyphosphogluconate aldolase (EC 4.1.2.14)

$\alpha$-Glucosidase (EC 3.2.1.20)

Ketoglutarate semialdehyde dehydrogenase (EC 1.2.1.26)

Endo-1,4- $\beta$-xylanase A precursor (EC 3.2.1.8)

2-dehydro-3-deoxygalactonokinase (EC 2.7.1.58)

2-dehydro-3-deoxyphosphogalactonate aldolase (EC 4.1.2.21)

$\beta$-Xylosidase (EC 3.2.1.37)

$\beta$-Xylosidase (EC 3.2.1.37)

Xylulose kinase (EC 2.7.1.17)

Xylose isomerase (EC 5.3.1.5)

D-xylose proton-symporter XylE

$\beta$-Xylosidase (EC 3.2.1.37)

$\beta$-Xylosidase (EC 3.2.1.37)

Xylose isomerase (EC 5.3.1.5)

$\beta$-Xylosidase (EC 3.2.1.37)

Phosphate regulon sensor protein $\mathrm{PhoR}$ (SphS) (EC 2.7.13.3)

Phosphate regulon transcriptional regulatory protein $\mathrm{PhoB}(\mathrm{SphR})$

Phosphate ABC transporter, periplasmic phosphate-binding protein

Phosphate transport system regulatory protein $\mathrm{PhoU}$

Phosphate transport ATP-binding protein PstB (TC 3.A.1.7.1)

Phosphate transport system permease protein PstA (TC 3.A.1.7.1)

Phosphate transport system permease protein PstC (TC 3.A.1.7.1)

Polyphosphate kinase (EC 2.7.4.1)

L-proline glycine betaine ABC transport system permease protein ProV

L-proline glycine betaine binding $\mathrm{ABC}$ transporter protein ProX

(TC 3.A.1.12.1) / Osmotic adaptation

Choline dehydrogenase (EC 1.1.99.1)

Betaine aldehyde dehydrogenase (EC 1.2.1.8)

High-affinity choline uptake protein BetT

Flagellar motor rotation protein MotB

Flagellar motor rotation protein MotA

\begin{tabular}{|c|c|}
\hline 3.85 & 0 \\
\hline 3.24 & 0 \\
\hline 3.24 & 0 \\
\hline 3.31 & 0 \\
\hline 4.03 & 0 \\
\hline 3.68 & 0 \\
\hline 2.95 & 0 \\
\hline 3.57 & 0 \\
\hline 3.29 & 0 \\
\hline 0.93 & 4.12E-271 \\
\hline 2.74 & 0 \\
\hline 0.02 & 0.01446 \\
\hline 0.25 & $4.28 \mathrm{E}-06$ \\
\hline 3.32 & 0 \\
\hline 1.22 & 0 \\
\hline 1.42 & 0 \\
\hline-0.38 & $2.36 \mathrm{E}-22$ \\
\hline 0.07 & 0.043192 \\
\hline 4.98 & 0 \\
\hline-0.47 & $5.72 \mathrm{E}-10$ \\
\hline 1.49 & 0 \\
\hline 1.27 & 0 \\
\hline 0.46 & 0.000184 \\
\hline 6.20 & 0 \\
\hline 1.36 & 0 \\
\hline 0.02 & 0.035184 \\
\hline-1.18 & 0 \\
\hline 2.49 & 0 \\
\hline-0.46 & $3.19 \mathrm{E}-38$ \\
\hline 2.15 & 0 \\
\hline 2.46 & 0 \\
\hline 0.93 & $4.45 \mathrm{E}-81$ \\
\hline 1.52 & $3.75 \mathrm{E}-109$ \\
\hline-0.91 & 0 \\
\hline-0.65 & $1.43 \mathrm{E}-271$ \\
\hline-1.20 & 0 \\
\hline-1.42 & 0 \\
\hline 0.12 & 0.002602 \\
\hline-0.81 & 0 \\
\hline 0.11 & 0.03591 \\
\hline 3.33 & 0 \\
\hline 2.80 & 0 \\
\hline 2.79 & 0 \\
\hline 3.12 & 0 \\
\hline 5.61 & 0 \\
\hline 1.44 & 0 \\
\hline 3.72 & 0 \\
\hline 3.38 & 0 \\
\hline 3.08 & 0 \\
\hline 1.53 & 0 \\
\hline 1.53 & 0 \\
\hline 1.64 & 0 \\
\hline 2.44 & 0 \\
\hline 2.49 & 0 \\
\hline 3.14 & 0 \\
\hline-0.45 & $2.44 \mathrm{E}-133$ \\
\hline 0.20 & $1.96 \mathrm{E}-10$ \\
\hline
\end{tabular}


Table 1. (continued from previous page)

\begin{tabular}{|c|c|c|c|}
\hline \multirow[b]{2}{*}{ GeneID } & \multirow[b]{2}{*}{ Function } & \multicolumn{2}{|c|}{ Ratio (plant/M9) } \\
\hline & & Fold change $\left(\log _{2}\right)$ & $P$ value \\
\hline Xag1926 & Flagellar synthesis regulator FleN & -1.31 & 0 \\
\hline Xag1927 & Flagellar biosynthesis protein FlhF & -2.06 & 0 \\
\hline Xag1928 & Flagellar biosynthesis protein FlhF & -1.32 & 0 \\
\hline Xag1930 & Flagellar biosynthesis protein FlhA & -1.55 & 0 \\
\hline Xag1931 & Flagellar biosynthesis protein FlhB & -1.85 & 0 \\
\hline Xag1935 & Flagellar biosynthesis protein FliR & -2.15 & 0 \\
\hline Xag1945 & Flagellum-specific ATP synthase FliI & -0.68 & $1.04 \mathrm{E}-252$ \\
\hline Xag1970 & Flagellar L-ring protein FlgH & -2.50 & 0 \\
\hline Xag1974 & Flagellar basal-body rod modification protein FlgD & -2.36 & 0 \\
\hline Xag3475 & Flagellar motor rotation protein MotA & 0.78 & $8.13 \mathrm{E}-134$ \\
\hline Xag3476 & Flagellar motor rotation protein MotB & 1.88 & 0 \\
\hline Xag1925 & RNA polymerase sigma factor for flagellar operon & -0.67 & 0 \\
\hline Xag1936 & Flagellar biosynthesis protein FliQ & -3.02 & 0 \\
\hline Xag1937 & Flagellar biosynthesis protein FliP & -1.98 & 0 \\
\hline Xag1938 & Flagellar biosynthesis protein FliO & -2.14 & 0 \\
\hline Xag1941 & Flagellar biosynthesis protein FliL & -3.42 & 0 \\
\hline Xag1943 & Flagellar hook-length control protein FliK & -0.14 & $3.82 \mathrm{E}-12$ \\
\hline Xag1944 & Flagellar protein FliJ & -0.61 & $2.33 \mathrm{E}-157$ \\
\hline Xag1946 & Flagellar assembly protein $\mathrm{FliH}$ & -0.65 & $3.83 \mathrm{E}-242$ \\
\hline Xag1948 & Flagellar M-ring protein FliF & -2.88 & 0 \\
\hline Xag1949 & Flagellar hook-basal body complex protein FliE & -3.22 & 0 \\
\hline Xag1957 & Flagellar regulatory protein FleQ & -0.75 & 0 \\
\hline Xag1963 & Flagellar biosynthesis protein FliS & -0.23 & $2.82 \mathrm{E}-32$ \\
\hline Xag1964 & Flagellar hook-associated protein FliD & -2.41 & 0 \\
\hline Xag1965 & Flagellar biosynthesis protein FliC & 0.84 & 0 \\
\hline Xag1966 & Flagellar hook-associated protein FlgL & -0.56 & $3.37 \mathrm{E}-71$ \\
\hline Xag1967 & Flagellar hook-associated protein FlgK & -1.73 & 0 \\
\hline Xag1968 & Flagellar protein FlgJ [peptidoglycan hydrolase] (EC 3.2.1.-) & -1.34 & 0 \\
\hline Xag1969 & Flagellar P-ring protein FlgI & -1.81 & 0 \\
\hline Xag1971 & Flagellar basal-body rod protein FlgG & -2.58 & 0 \\
\hline Xag1972 & Flagellar basal-body rod protein FlgF & -1.27 & 0 \\
\hline Xag1973 & Flagellar hook protein FlgE & -1.60 & 0 \\
\hline Xag1975 & Flagellar basal-body rod protein FlgC & -1.72 & 0 \\
\hline Xag1976 & Flagellar basal-body rod protein FlgB & -3.67 & 0 \\
\hline Xag1978 & Flagellar basal-body P-ring formation protein FlgA & -2.02 & 0 \\
\hline Xag1904 & Flagellar motor rotation protein MotB & -1.87 & $7.25 \mathrm{E}-09$ \\
\hline \multicolumn{4}{|l|}{ TypeIV pilli } \\
\hline Xag2757 & Twitching motility protein PilT & -1.07 & 0 \\
\hline Xag3062 & Two-component sensor PilS & -0.22 & $6.01 \mathrm{E}-12$ \\
\hline Xag3063 & Type IV fimbriae expression regulatory protein PilR & 0.05 & 0.009653 \\
\hline Xag3064 & Type IV fimbrial assembly, ATPase PilB & -1.20 & $1.92 \mathrm{E}-261$ \\
\hline Xag3065 & Type IV fimbrial assembly, ATPase PilB & -1.32 & 0 \\
\hline Xag3067 & Type IV fimbrial assembly protein PilC & -1.61 & 0 \\
\hline Xag3173 & Type IV pilus biogenesis protein PilQ & -0.65 & 0 \\
\hline Xag3174 & Type IV pilus biogenesis protein PilQ & -0.15 & $1.39 \mathrm{E}-22$ \\
\hline Xag3175 & Type IV pilus biogenesis protein PilP & -0.47 & $8.56 \mathrm{E}-265$ \\
\hline Xag3176 & Type IV pilus biogenesis protein PilO & -0.49 & 0 \\
\hline Xag3177 & Type IV pilus biogenesis protein PilN & -1.26 & 0 \\
\hline Xag3178 & Type IV pilus biogenesis protein PilM & -0.83 & 0 \\
\hline Xag3068 & $\begin{array}{l}\text { Leader peptidase (prepilin peptidase) } \\
\text { (EC 3.4.23.43)/N-methyltransferase (EC 2.1.1.-) }\end{array}$ & -1.19 & 0 \\
\hline
\end{tabular}

variety of living organisms (Lu and Holmgren 2014). The genes encoding peroxiredoxins (XagID1161) and bacterioferritin (XagID1160) as well as those for several general stress response proteins that might protect $X$. axonopodis $\mathrm{pv}$. glycines from oxidative stress at the infection sites were significantly induced in planta.

The expression of $X$. axonopodis pv. glycines genes encoding choline dehydrogenase, betaine aldehyde dehydrogenase, and the high-affinity choline uptake protein BetT (XagID749-751) in $X$. axonopodis pv. glycines were significantly induced in the soybean apoplast. The genes involved in betaine catabolism and trehalose biosynthesis in P. syringae pv. syringae have recently been shown to be induced within plants (Yu et al. 2013). These genes also have been reported to play a role in osmotolerance and in fitness on bean leaves ( $\mathrm{Li}$ et al. 2013). The trehalose biosynthesis genes of $X$. axonopodis pv. glycines were also induced in planta. Trehalose is a common metabolite that has been shown to be involved in conferring tolerance to a variety of environmental stresses, such as low water availability due to high salinity or desiccation, freezing, heat, and oxidative stress (Freeman et al. 2010; Li et al. 2013; Yu et al. 2013), suggesting that $X$. axonopodis pv. glycines may experience relatively low water availability in the apoplast of soybean during the infection process, a surprising finding also noted in plants infected by Pseudomonas syringae (Li et al. 2013; Yu et al. 2013).

A variety of other genes important to behavior and global regulation in $X$. axonopodis pv. glycines, including those involved in chemotaxis, a gene encoding an ECF sigma factor, and the gene encoding RpfN, a regulator of diffusible signal factor-mediated quorum sensing system, were also highly expressed in planta. Moreover, various other genes encoding 
A

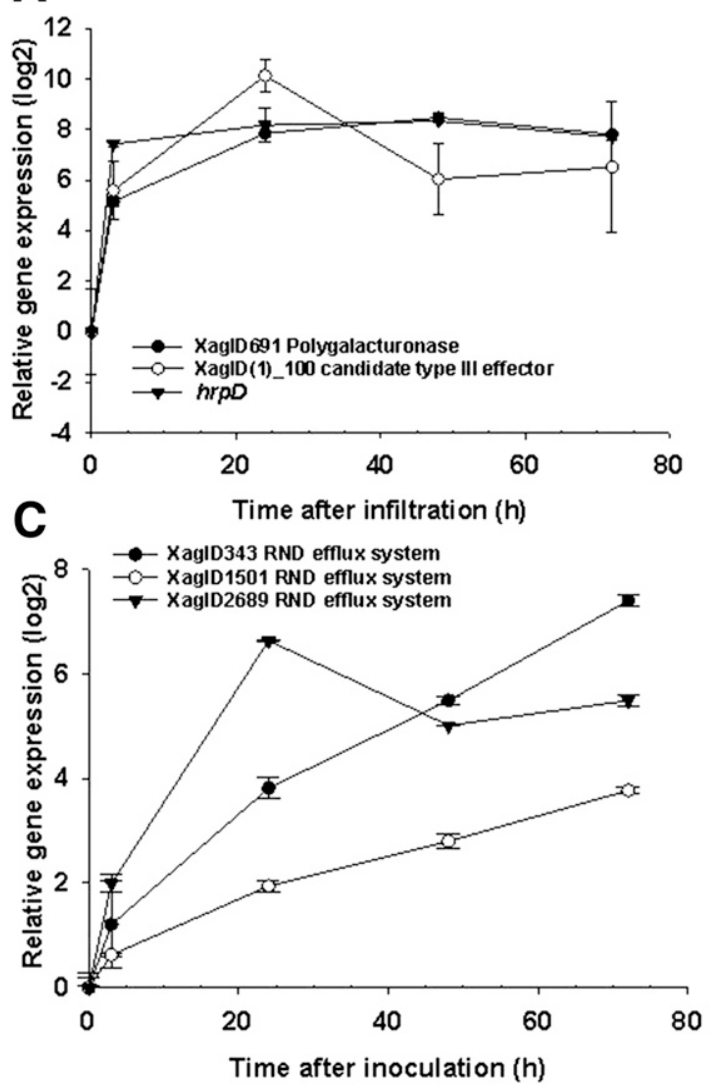

B
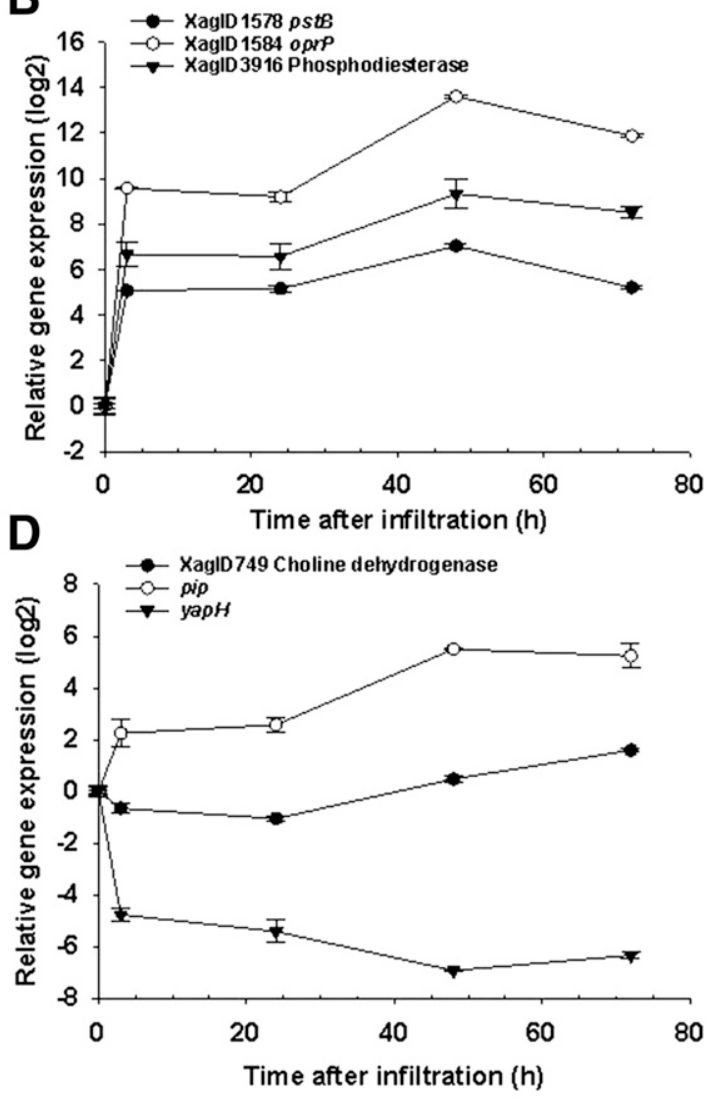

Fig. 1. A, Expression of genes encoding polygalacturonase, typeIII effector, and HrpD; B, phosphate transporter proteins; C, RND multidrug efflux pumps; and $\mathbf{D}$, choline dehydrogenase, proline iminopeptidase (pip), and the adhesin YapH, as determined by quantitative reverse transcription-polymerase chain reaction at various times after infiltration into soybean leaves. The vertical bars represent the standard deviations of the mean ratio of that compared with in vitro conditions. Similar results were obtained in repeated independent experiments.

proteins with unknown function or showing no similarity to other proteins were also induced.

The expression of a variety of genes involved in attachment and motility were down-regulated in $X$. axonopodis pv. glycines in planta (Table 1). As do many bacteria, Xanthomonas species synthesize both fimbrial and afimbrial adhesins that mediate their attachment to surfaces. Such adhesins can contribute to virulence (Das et al. 2009; Gottig et al. 2009; Ray et al. 2002), but, depending on the particular stage in the infection process, their presence could interfere with active movement or dispersal processes involved in secondary infection events. The fimbrial adhesins of $X$. axonopodis pv. glycines include filamentous hemaglutinin-like proteins, such as homologs of the autotransporter adhesin YapH from Yersinia spp. and other proteins (XadA and $\mathrm{XadB}$ ) that are related to YadA from Yersinia spp. Fimbrial adhesins include type IV pili and related proteins, such as the type IV pilus secretin PilQ. The genes encoding a putative hemolysin activation protein, sigmafimbriae tip adhesin, and genes encoding type IV fimbrial biogenesis protein and type IV pilus biogenesis protein were all suppressed in planta. The gene encoding the adhesin YapH (XagID2132) was particularly strongly down-regulated in planta. The luxR homolog XagR had been found to modulate the adhesiveness of $X$. axonopodis pv. glycines during the infection process by suppressing $\mathrm{YapH}$, apparently in response to the perception of unidentified small molecules released into the apoplast during the latter stages of the infection process (Chatnaparat et al. 2012). This current study, therefore, confirms these earlier observations and suggests that at least some of the cells of $X$. axonopodis pv. glycines had experienced chemical cues from the infected plant that triggered a conversion to a nonadhesive phenotype that presumably would enable its escape from the apoplast to initiate secondary infections. The observation that many $X$. axonopodis pv. glycines genes that would contribute to active motility, including those encoding an RNA polymerase sigma factor for flagellar operon flagellar synthesis regulator (XagID1925), flagellar motor proteins (XagID1904-1905), flagellar biosynthesis protein (XagID1926-1941), flagellar hook-associated protein, and flagellar basal-body rod protein (XagID1963-1978) were expressed at lower levels in planta compared with a minimal medium

\section{Temporal expression pattern of some plant-inducible genes during the infection process.}

To better understand the behavior of $X$. axonopodis pv. glycines at various stages during the infection process, we investigated the expression of some of the plant-inducible genes, using quantitative RT-PCR. Expression of genes representing various processes, including the T3SS ( $h r p D)$ and putative type III effector protein (XagID(1)_100), CWDE PG (XagID691), phosphate transporters (XagID1578, XagID1584, XagID3916), RND efflux pumps (XagID343, XagID1501, XagID2689), and genes controlled by XagR (pip, yapH, and the choline dehydrogenase encoded by XagID749), was assessed at various times in the first 3 days after inoculation of soybean (Fig. 1). Many genes, such as those encoding the T3SS and effector proteins and CWDE (Fig. 1A) as well as phosphate transporters (Fig. 1B) were strongly expressed immediately after infection, while several RND efflux pumps (Fig. 1C) were highly 
expressed only 1 day or more after infection. As expected, pip was most highly expressed and yapH (Fig. 1D) was most strongly repressed 2 days or more after infection, since they are controlled by XagR, a regulator that accumulates primarily at late stages of infection.

\section{Contribution of plant-inducible genes to the virulence} of $X$. axonopodis pv. glycines.

Although a few of the plant-inducible genes described here, including those encoding the hrp cluster, the cell wall-degrading enzyme protease, endoglucanase, and pectate lyase, Pip and YapH contribute to the virulence of $X$. axonopodis pv. glycines, the role of genes that were predominantly expressed in planta has not been established. We, thus, disrupted three different RND multidrug efflux pumps (XagID2689, XagID343 and XagID1501), the malonate decarboxylase operon $(m d c)$, and the high-affinity phosphate transport operon (phoU-pstSCAB) to assess their role in the virulence of $X$. axonopodis pv. glycines.

\section{Efflux pumps.}

The three different RND multidrug efflux pumps differed greatly in their contribution to the virulence of $X$. axonopodis pv. glycines. While the disruption of efflux pump XagID2689 greatly reduced the virulence of $X$. axonopodis pv. glycines, disease severity conferred by the knockout mutant of XagID343 was only modestly reduced and that of XagID1501 was similar compared with that of the wild-type strain (Fig. 2A). The population sizes of these knockout mutants were generally directly related to the virulence that they exhibited (Fig. 2B). The population size attained by the XagID2689 knockout mutant was significantly lower than that of the wild-type strain, particularly at early stages of the infection process (Fig. 2B). In

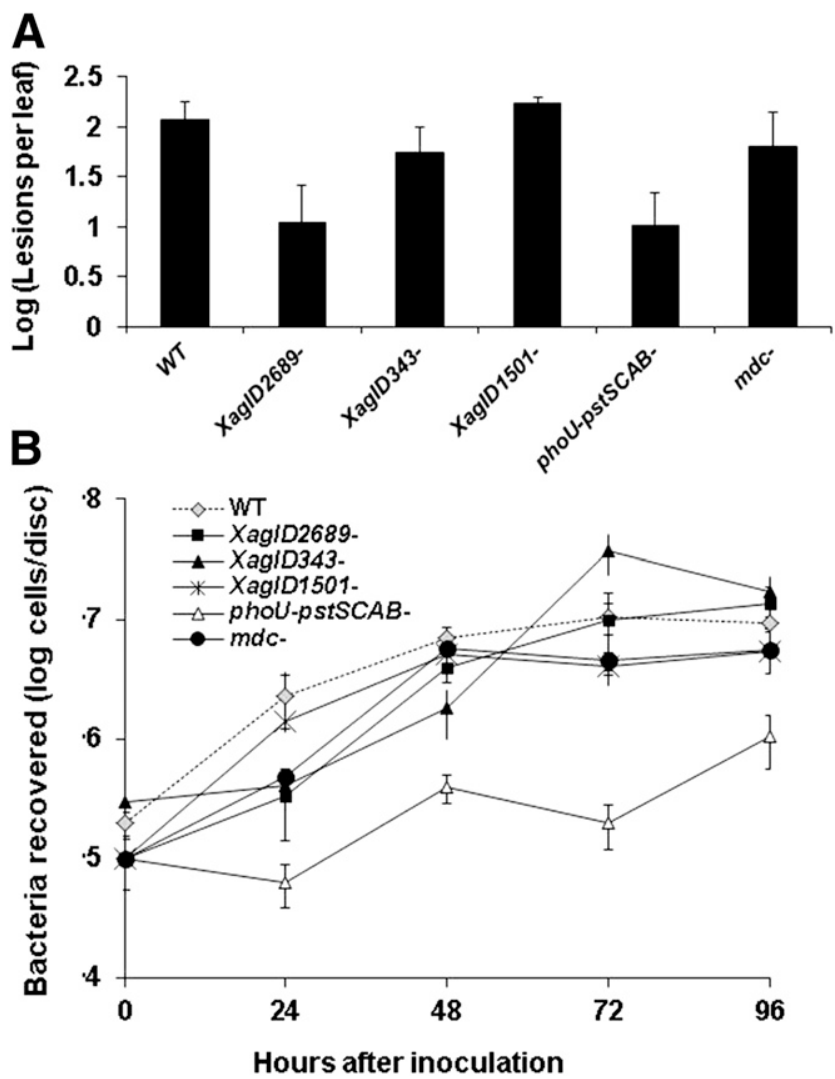

Fig. 2. A, Incidence of bacterial pustule disease on soybean incited by different strains of Xanthomonas axonopodis pv. glycines after spray inoculation on susceptible soybean and $\mathbf{B}$, growth of these strains after infiltration into susceptible soybean. The vertical bars represent the standard deviation of the mean. contrast, the population size of the XagID343 mutant was modestly reduced early in the infection process and that of the XagID1501 mutant was similar to that of the wild-type strain (Fig. 2B). It is noteworthy that XagID2689 was apparently expressed at a substantially higher level than the other efflux pumps, and its greater contribution of variance may have been due to its greater potential for removal of toxic plant products from $X$. axonopodis pv. glycines. Given the dominant role of XagID2689 in virulence, we explored in more depth the factors leading to its induction and the functions that it conferred that contributed to $X$. axonopodis pv. glycines fitness.

Given that the XagID2689 mutant was strongly reduced in virulence to soybean, we tested the hypothesis that its larger role in virulence was due to its dominant role in tolerance of toxic substances. The susceptibility of the three different knockout mutants of the RND efflux pumps was determined by measuring the minimal inhibition concentration (MIC) of various antibiotics and toxins in vitro compared with the parent strain. XagID2689 was the only mutant that exhibited altered susceptibility to the tested compounds, which included the isoflavonoids naringenin, phloretin, and berberine, as well as the antibiotics acriflavin and tetracyclin in vitro (Table 2). Disruption of XagID343 and XagID1501 had no effect on antimicrobial susceptibility. These results suggested that XagID2689 plays a major role in resistance toward soybean phytoalexins in $X$. axonopodis pv. glycines, presumably by serving as an export pump, reducing intracellular concentrations to subinhibitory levels.

To determine whether the compounds identified as substrates of XagID2689 also activated its expression, we introduced plasmid pXag2689:GFP, in which the native promoter of xagID2689 was fused with a promoterless green fluorescent protein (GFP) reporter gene into the wild-type strain, and GFP fluorescence was determined in the presence and the absence of various antimicrobial compounds of plant origin in vitro. The promoter activity of xagID2689 was most strongly increased in vitro in the presence of naringenin, with phloretin and quercetin also serving as strong inducers of this efflux pump (Fig. 3A). It is noteworthy that the xagID2689 promoter was not responsive to a variety of other compounds including (+)-catechin, berberine, acriflavin, salicylic acid, ferulic acid, and benzoic acid (Fig. 3A). Moreover, the promoter activity of xagID2689 was increased in direct proportion to the concentration of naringenin and phloretin (Fig. 3B). The high level of expression of xagID2689 seen in planta was, therefore, most likely due to the presence of these phytoalexins released during the infection process. As such toxicants would be expected to be generally present in a variety of plants exposed to potential pathogens, such as $X$. axonopodis pv. glycines, we addressed the expression of the xagID2689 promoter after the introduction of $X$. axonopodis pv. glycines into both compatible

Table 2. Sensitivity of Xanthomonas axonopodis pv. glycines mutants to different compounds

\begin{tabular}{lccrr}
\hline & \multicolumn{3}{c}{ Minimal inhibition concentrations $(\boldsymbol{\mu g} / \mathbf{m l})$} \\
\cline { 2 - 5 } Compound & Wild type & Xag2689- & Xag343- & Xag1501- \\
\hline Phloretin & 250 & 125 & 250 & 250 \\
Naringenin & 500 & 250 & 500 & 500 \\
Quercetin & $>1,000$ & $>1,000$ & $>1,000$ & $>1,000$ \\
DCatechin & $>1,000$ & $>1,000$ & $>1,000$ & $>1,000$ \\
Berbarine & 500 & 250 & 1,000 & $>1,000$ \\
Acriflavin & 25 & 6.25 & 25 & 25 \\
Tetracyclin & 100 & 50 & 50 & 50 \\
Erythomycin & 25 & 50 & 25 & 25 \\
Ferulic acid & 1,000 & 1,000 & 1,000 & 1,000 \\
Spectinomycin & 250 & 500 & 500 & 1,000 \\
Salicylic acid & $>1,000$ & 1,000 & 1,000 & 1,000 \\
\hline
\end{tabular}


and incompatible host plants. The xagID2689 promoter activity, determined by fluorescence intensity of individual cells as determined by microscopy of cells recovered from plants two days after inoculation, was induced in both the susceptible soybean cultivar Spencer as well as the resistant soybean cultivar Williams and the nonhost tomato (Fig. 3C). These results suggest that the RND-type XagID2689 pump is activated by phytoalexins, most likely a variety of isoflavonoids that are produced in response to interaction with the pathogen.

\section{Malonate metabolism.}

Since the C3-dicarboxylic acid malonate is abundant in legumes and we found that genes encoding malonate decarboxylase $(m d c)$ that presumably enable the consumption of malonate (XagID590-594) to be strongly induced in planta, we tested the model that $X$. axonopodis pv. glycines exploits malonate for growth in the apoplast. The ability of a $m d c$ mutant to grow in minimal media with malonate as the sole carbon source and in planta was examined. The $m d c$ mutant and the wild-type strain were grown in M9 liquid medium containing $20 \mathrm{mM}$ malonate, $10 \mathrm{mM}$ sucrose, $20 \mathrm{mM}$ succinate, or $20 \mathrm{mM}$ malonate, plus either sucrose or succinate. The $m d c$ mutants exhibited almost no growth in minimal media with $20 \mathrm{mM}$ malonate as the sole carbon source, while the wild-type strain exhibited substantial growth (Fig. 4A). The growth of the $m d c$ mutant could be restored in malonate minimal media by introducing a plasmid carrying the $m d c$ operon (Fig. 4A). To test the assumption that the induction of the malonate decarboxylase operon was, in fact, due to the perception of malonate by $X$. axonopodis pv. glycines, we examined the expression of the gene encoding malonate decarboxylase delta subunit $(\mathrm{mdcD}$ [XagID591]) in X. axonopodis pv. glycines by RT-PCR in cells grown in the presence or absence of malonate and other carbon sources. $m d c D$ expression was strongly induced in the presence of malonate but not by either sucrose or succinate (Fig. 4B). Furthermore, expression of $m d c D$ in the presence of malonate was not appreciably suppressed when either $10 \mathrm{mM}$ sucrose or $10 \mathrm{mM}$ succinate was also present, suggesting that expression of malonate catabolism is not strongly susceptible to catabolize repression by other carbon sources that may be preferentially consumed by $X$. axonopodis pv. glycines. It thus seems apparent that $X$. axonopodis pv. glycines actively consumes malonate in the apoplast of soybean. Interestingly, disruption of the malonate decarboxylase operon led to little reduction in the virulence of X. axonopodis pv. glycines to soybean (Fig. 2A) and only modest reductions in the population sizes, achieved within the soybean apoplast after infiltration, that were not statistically significant from the wild-type strain (Fig. 2B). The fitness of the $m d c$ mutant was very similar to that of the wild-type strain, as no significant change in the ratio of these two strains, originally inoculated at similar proportions into soybean, were observed with time after inoculation (Supplementary Fig. S2). In aggregate, these observations suggest that, although $X$. axonopodis pv. glycines consumes malonate in the apoplast of soybean, it is likely only one of several such carbon compounds available, others of which
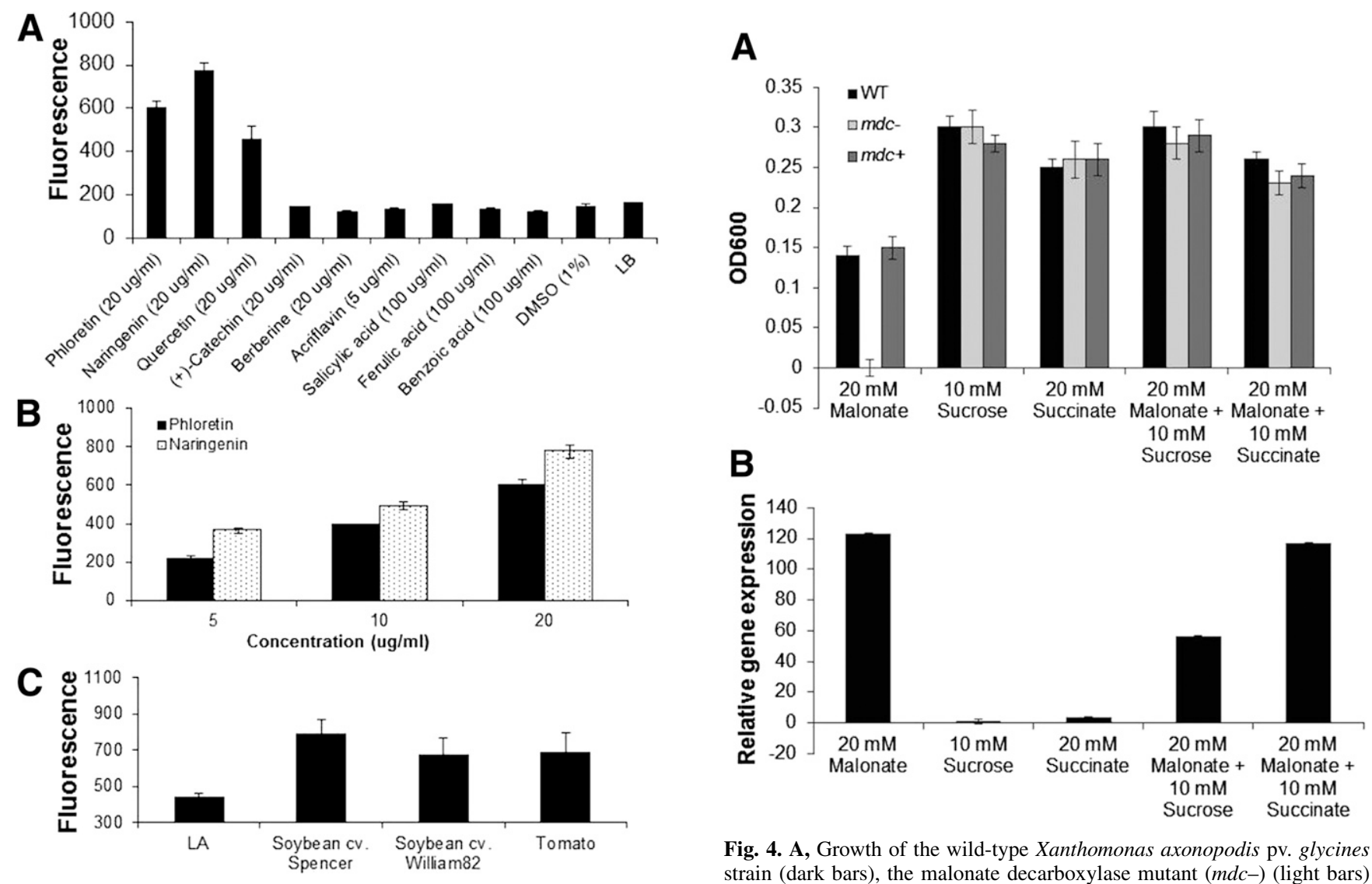

Fig. 4. A, Growth of the wild-type Xanthomonas axonopodis pv. glycines strain (dark bars), the malonate decarboxylase mutant ( $\left.m d c^{-}\right)$(light bars) and $m d c$ complemented strain $(m d c+)$ (intermediate bars) and $\mathbf{B}$, expression of the gene encoding malonate decarboxylase $\Delta$ subunit ( $m d c D$ [XagID591]) when grown in M9 minimal media containing different carbon sources, as determined by quantitative reverse transcription-polymerase chain reaction. The vertical bars represent the standard deviation of the mean population size or ratio of gene expression compared with that of cells grown in M9 minimal supplemented with $10 \mathrm{mM}$ sucrose. Xanthomonas axonopodis pv. glycines harboring a pXag2689:gfp fusion when grown in culture media containing various compounds, B, when grown in media containing different concentrations of two phytoalexins, and $\mathbf{C}$, when inoculated into soybean and tomato plants. The vertical bars represent the standard deviation of the mean of relative fluorescence. 
may be either more abundant or more readily catabolized by the pathogen. Thus, malonate is apparently only a minor resource for $X$. axonopodis pv. glycines growth in soybean.

\section{Phosphorous metabolism.}

Given that the transcription of the pst operon (phoU-pstSCAB) and other genes involved in phosphate metabolism and uptake of $X$. axonopodis pv. glycines were induced in planta, we investigated the contribution of this operon to its virulence and growth under phosphate limitation conditions. The virulence of a phoU-pstSCAB deletion mutant of $X$. axonopodis pv. glycines was significantly lower than that of the wild-type strain (Fig. 2A). Likewise, this mutant grew much less rapidly in soybean after inoculation, attaining population sizes that were about 100-fold less than that of the wild-type strain at a given sampling time (Fig. 2B). Surprisingly, however, the reduced growth of the phoU-pstSCAB mutant in planta was not apparently associated was a deficiency in phosphate acquisition. The growth rate of the phoU-pstSCAB mutant and the wild-type strain were compared in a low phosphatecontaining MOPS minimal media with different concentration of added $\mathrm{KPO}_{4}$. Similar growth rates and cell yields of the mutant and wild-type strains were observed (data not shown). It seems apparent, therefore, that other transporters in $X$. axonopodis pv. glycines allowed sufficient phosphate uptake to enable phoU-pstSCAB mutants to grow in phosphatelimiting minimal medium and that the phoU-pstSCAB operon plays additional roles in the interactions of $X$. axonopodis $\mathrm{pv}$. glycines with soybean.

\section{DISCUSSION}

This study of the global gene expression profiles of $X$. axonopodis pv. glycines during its infection of soybean has provided a wealth of information about both virulence traits involved in the interaction as well as the chemical and physical environment within the infection court. RNA-Seq proved to be both a practical and sensitive method by which pathogen transcript abundance could be quantified. A hurdle that we successfully overcame was to identify methodologies by which $X$. axonopodis pv. glycines cells could be separated from host tissue in a way that both retained their integrity but also minimized their contamination with eukaryotic RNA. Given that about $60 \%$ of the total reads of cDNA could be mapped to the $X$. axonopodis pv. glycines draft genome, it appears that the method by which pathogen cells could be made to diffuse from infected plant tissue after minimal disruption of the leaf, similar to that used by Yu et al. (2013), would prove useful in the study of other plantmicrobe interactions. $X$. axonopodis pv. glycines clearly alters expression of a large variety of genes to successfully interact with soybean during the infection process, since at least 823 genes ( $16 \%$ of the total number of genes) of $X$. axonopodis pv. glycines were differentially expressed in the soybean apoplast.

RNA-seq analysis reveals that $X$. axonopodis pv. glycines activates the T3SS and effector proteins into the host cell. Most pathogenic xanthomonads possess a T3SS to inject effectors into the host cells (Ryan et al. 2011), and T3SS is critical to $X$. axonopodis pv. glycines pathogenicity and virulence (Kim et al. 2003). A variety of pathogenicity and virulence genes of plant-pathogenic bacteria have been shown to be induced in planta. For example, the transcription of genes encoding the type III protein secretion system, effector proteins, and phytotoxins are strongly up-regulated in various species (Boch et al. 2002; Boureau et al. 2002; Jacobs et al. 2012; Tamir-Ariel et al. 2007; Zhao et al. 2005). In some taxa, such as Xanthomonas spp., such virulence genes were associated with a PIP box (plant-inducible promoter) that apparently enabled its induction in planta (Tamir-Ariel et al. 2007). The regulators HrpG, an OmpR family regulator, and HrpX, an AraC-type transcriptional activator, control the expression of the T3SS in several Xanthomonas species (Büttner and Bonas 2010; Guo et al. 2011; Kim et al. 2003; Rossier et al. 1999; Wengelnik et al. 1999). In this study, the expression of $h r p X$ but not $h r p G$ was significantly upregulated in $X$. axonopodis pv. glycines in soybean. This contrasts with observations made with Xanthomonas campestris pv. vesicatoria carrying either a $h r p G$-gfp or a $h r p X$-gfp reporter gene construct that revealed that expression of $h r p X$ was similar to that of $h r p G$ at various times after inoculation into tomato leaves (Zhang et al. 2009). HrpG, which is apparently at the top of the T3SS regulatory cascade (Wengelnik et al. 1999), induces expression of $h r p X$, which, in turn, activates transcription of the operons $h r p B$ to $h r p F$ (Rossier et al. 1999). Given that the transcriptome of $X$. axonopodis pv. glycines was analyzed three days after infiltration of cells into soybean, these results suggest that $h r p G$-mediated regulation was still operative at this early stage of infection but that, if it is only transiently expressed, as is apparently the case in $X$. campestris pv. vesicatoria, it may not be expressed in later stages of the infection process. Our analysis of transcript abundance by qRT-PCR at various times also revealed that the T3SS structural gene $h r p D$ was strongly expressed as early as $3 \mathrm{~h}$ after inoculation, suggesting that plant-derived signals induce T3SS genes of $X$. axonopodis pv. glycines nearly immediately after they enter the apoplast.

CWDE, such as PG, cellulases, xylanases, and proteases secreted by the T2SS are important virulence determinants of many plant pathogens. Two PG genes of $X$. axonopodis pv. glycines were found to be strongly up-regulated at early stages of infection. This observation is consistent with that seen for the expression of PGs of E. amylovora, Ralstonia solanacearum, and $X$. campestris pv. campestris that were strongly induced in planta (Collmer and Keen 1986; Schacht et al. 2011; Zhao et al. 2005). While knockout of genes encoding PGs attenuate the virulence of many bacteria (Liu et al. 2005; Wang et al. 2008), the role that $\mathrm{PG}$ plays in the interaction of $X$. axonopodis pv. glycines with soybean is unknown, although pectate lyase (pel), plays a role in its induction of a hypersensitive response on nonhost plants (Kaewnum et al. 2006). Since the in planta expression of a PG in Xcc8004 was controlled by HrpG and HrpX (Wang et al. 2008), it is noteworthy that we also found that the expression of the $X$. axonopodis pv. glycines PG was also upregulated early in the infection process, as were genes encoding the T3SS. Moreover, two $X$. axonopodis pv. glycines xylanases were also up-regulated. Xylanases from $X$. campestris pv. campestris, $X$. campestris pv. vesicatoria, and $X$. oryzae pv. oryzae were shown to contribute to their virulence (Rajeshwari et al. 2005; Sun et al. 2005; Solé et al. 2015; Szczesny et al. 2010). Both PG and xylanase play a role in plant cell-wall degradation and promotes bacterial invasion and, probably, provide carbon resources in the apoplast. These enzymes also can elicit plant defense responses (Beliën et al. 2006; Déjean et al. 2013; Santos et al. 2014). It is possible that $X$. axonopodis pv. glycines primarily employs $\mathrm{PG}$ and xylanase to degrade the pectin and xylan that are in high abundance in soybean plant cell wall cells to both release nutrients into the apoplast and to facilitate the translocation of effectors into plant cells during the infection process. Further study of the role of these enzymes in $X$. axonopodis pv. glycines should prove fruitful.

Other genes identified in this study may point to the various strategies $X$. axonopodis pv. glycines uses to gain access to nutrients. Plant inducible genes in other studies have also identified genes that may enable the pathogen to be otherwise compatible with the environment found within the plant, such as those involved in stress tolerance, polysaccharide synthesis, nutrient uptake, amino acid assimilation, and carbon 
metabolism (Jacobs et al. 2012; Yu et al. 2013; Zuluaga et al. 2013). Our results showed $X$. axonopodis pv. glycines genes involved in malonate metabolism are induced in planta as well as by malonate, indicating that it encounters this organic acid in the apoplast. Malonate is present in large concentrations in all parts of the soybean plant (Stumpf and Burris 1981; Karunakaran et al. 2013) and plays a role in soybean-microbe interactions. For instance, malonate metabolism contributes to the formation of nitrogen-fixing nodules elicited by Rhizobium leguminosarum bv. trifolii in clover (An et al. 2002). In contrast, mutants of Sinorhizobium meliloti and R. leguminosarum biovars viciae and trifolii that could not catabolize malonate did not decrease $\mathrm{N}_{2}$ fixation in either alfalfa or clover (Chen et al. 2010; Karunakaran et al. 2013). Consistent with such a finding, the $m d c$ mutant of $X$. axonopodis pv. glycines, which was incapable of malonate catabolism, was not significantly reduced in either its virulence in soybean or in the apoplastic population sizes achieved. Such a finding might be rationalized, given that the genes encoding fructose transport into the cell were also induced in planta, suggesting that $X$. axonopodis pv. glycines also experiences this sugar that is likely an abundant resource in the apoplast (Tukey 1970). Sugars such as fructose or sucrose may also be a preferred carbon source for $X$. axonopodis pv. glycines, given that a higher number of cells were produced in culture media containing these compounds compared with that in media containing malonate as a sole carbon source (Fig. 4). It is noteworthy, however, that expression of the $m d c$ operon was not apparently subject to repression by either sucrose or succinate in media also containing malonate (Fig. 4). These results, therefore, suggest that $X$. axonopodis pv. glycines apparently facultatively utilizes malonate as a carbon source.

The upregulation of $X$. axonopodis pv. glycines genes involved in compatible solute metabolism in planta suggests that it experiences low water availability in the apoplast. Choline, glycine betaine, and proline can all function as compatible solutes that are important for bacterial osmoadaptation. Multiple transporters mediating osmoregulatory solute accumulation was identified in the genome of $X$. axonopodis pv. glycines, and those that contribute to choline uptake and metabolism were significantly induced in planta. However, the expression of genes encoding putative glycine betaine or proline transporters did not differ in planta from that in a minimal medium. These results indicated that choline is probably abundant in soybean leaves and, as shown in P. syringae (Chen and Beattie 2008; Chen et al. 2013), is used by $X$. axonopodis pv. glycines to tolerate water stress in the apoplast. In addition, we had previously found that choline dehydrogenase and betaine aldehyde dehydrogenase were induced by XagR, a regulator that accumulates only late in the infection process in soybean (Chatnaparat et al. 2012), suggesting that water withholding may be one defense utilized by soybean to limit colonization of $X$. axonopodis pv. glycines after infection, similar to that observed in tomato inoculated with P. syringae (Beattie 2011; Chen and Beattie 2008).

Several multidrug transporters in $X$. axonopodis pv. glycines were induced in planta and, given that such transporters are usually induced by the toxic compounds that they export, suggesting that it experienced such compounds in the apoplast. In plant pathogens, multidrug efflux systems apparently protect against plant toxic compounds (Burse et al. 2004; Palumbo et al. 1998; Pletzer and Weingart 2014b; Ravirala et al. 2007; Stoitsova et al. 2008; Vargas et al. 2011). Isoflavones are particularly abundant in plants in the family Leguminosae, especially in soybeans (Cavaliere et al. 2007). While several RND efflux pumps were induced in soybean, the genes encoding several other efflux pumps were not, suggesting that these exporters play distinct roles in X. axonopodis pv. glycines. It was noteworthy that, while the XagID2689, XagID343, and
XagID1504 efflux pumps were all strongly up-regulated in soybean, only XagID2689 distributed substantially to resistance toward soybean isoflavones and to the virulence of $X$. axonopodis pv. glycines (Fig. 2; Table 2). It seems likely that its dominant role in these processes may have been associated with its higher apparent abundance, as evidenced from the substantially higher induced levels of XagID2689 transcript observed compared with that of the other two RND efflux pumps. That is, while all exhibited fourfold or more induction in planta, the higher absolute levels of expression of XagID2689 likely accounted for its higher potential to export toxic substances. These results are consistent with findings in E. amylovora revealing that disruption of the RND efflux pump AcrD does not cause hypersusceptibility to antimicrobial compounds and did not exhibit reduced virulence in either apple rootstocks or immature pear fruits (Pletzer and Weingart 2014a and $b$ ). The potential for AcrD to contribute to these processes was, however, demonstrated by overexpressing it in an acrB-deficient mutant of E. amylovora, which led to increased resistance to several antimicrobial compounds (Pletzer and Weingart $2014 \mathrm{a}$ and $\mathrm{b}$ ). Thus, it is possible that the expression of XagID2689 was sufficiently high in the XagID342 and XagID1501 mutants that their deletion would have had very little effect on antimicrobial susceptibility and virulence. XagID2689 also appears to be relatively promiscuous in its conference of resistance to toxic compounds. Knockout of XagID2689 led to hypersensitivity to berberine and acriflavin, despite the fact that neither of these compounds contributed substantially to its induction (Table 2). Conversely, expression of XagID2689 was induced by compounds such as quercetin, to which it did contribute substantial resistance (Fig. 3). It was, however, noteworthy that expression of XagID2689 was induced by naringenin and phloretin (Fig. 3), flavonoids that would be expected to be found in soybean. In other bacteria, these flavonoids also activate the multidrug efflux pumps AcrAB and MexAB-OprM of E. amylovora and P. syringae pv. tomato, respectively (Burse et al. 2004; Slimestad et al. 2008; Vargas et al. 2011). Given that the RND efflux pumps were all highly induced within 1 to 2 days of inoculation, it appears that flavonoids are either rapidly induced or are constitutively present in soybean.

$X$. axonopodis pv. glycines also apparently experiences low phosphate availability during infection and responds by upregulating the genes involved in phosphate metabolism and transport. Phosphorus is an important element for all life forms and is often a limiting nutrient in natural environments, usually in the form of inorganic phosphate $(\mathrm{Pi})$. Bacterial responses to phosphorus limitation are important fitness determinants in environments (Lamarche et al. 2008). The Pho regulon is a global regulatory circuit involved in bacterial phosphate management and in pathogenesis (Lamarche et al. 2008). The PhoR-PhoB two-component regulatory system appears essential to coordinating the expression of phosphate-specific transporters encoded by pstSCAB as well as genes involved in phosphorus metabolism, such as a phytase to achieve phosphorus homeostasis. In several bacteria, the transcription of the pst operon is induced under conditions of phosphate starvation as well as in planta (Crépin et al. 2008; Lamarche et al. 2008; Moreira et al. 2015; Yang et al. 2004). In addition, several studies have linked extracellular phosphate $(\mathrm{Pi})$ availability and the Pst system to virulence and survival under stressful conditions (Crépin et al. 2011; Jacobsen et al. 2008; Lamarche et al. 2008; Pratt et al. 2010). For example, responses to $\mathrm{Pi}$ limitation stimulated both adherence to surfaces and biofilm formation in Agrobacterium tumefaciens (Danhorn et al. 2004; Xu et al. 2012). Disruption of pstB, encoding an ABC phosphate transporter in Xanthomonas citri, abolished citrus canker symptoms (Moreira et al. 2015). In this study, the 
mutation of the pst operon also greatly reduced the virulence of $X$. axonopodis pv. glycines to soybean and greatly reduced its apoplast growth in this host. These results further support a model that phosphorus is a limiting factor for bacterial growth in plants, although the other possible roles of phosphorus metabolism in virulence warrant further investigation.

$X$. axonopodis pv. glycines appears to take on a nonmotile yet nonadhesive phenotype during the process of infection of soybean. Several factors, such as fimbrial assembly proteins, type IV pili, and the adhesin $\mathrm{YapH}$ that are involved in attachment and flagellar motility of $X$. axonopodis pv. glycines, were all suppressed in planta. Previous studies had revealed that the downregulation of $\mathrm{YapH}$, which is repressed by XagR, which itself accumulates only late in the infection process, promotes egression of $X$. axonopodis pv. glycines from the apoplast onto the leaf surface (Chatnaparat et al. 2012). The findings here that other fimbriae that are also likely involved in attachment are also suppressed in the soybean apoplast further support the model that escape from infected tissue is an important aspect of the epidemiological cycle of $X$. axonopodis pv. glycines. $X$. axonopodis pv. glycines does not appear to be capable of active movement within the apoplast, given that most genes involved in flagellar function and chemotaxis are suppressed in this habitat. This finding is similar to that observed in $P$. syringae pv. syringae, in which flagellar genes were much more highly expressed on leaf surfaces than in the apoplast (Yu et al. 2013). In contrast, genes mediating adhesion and biofilm formation in the vascular pathogen $X$. oryzae $p v$. oryzae were highly expressed in the xylem of rice (Soto-Suárez et al. 2010). Clearly, bacterial pathogens appear to have a variety of different interactions with their host plant and such distinctive behaviors can be ascertained by global in-planta transcriptome analysis.

Global transcriptional profiling of $X$. axonopodis pv. glycines in planta has facilitated the discovery of the genetic elements associated with its adaptation to soybean and its traits that contribute to virulence. Many of the nutrient utilization and virulence traits present in $X$. axonopodis pv. glycines appear to be driven by the nature of the plant environment, such as malonate, which are abundant in soybean, phosphorus, and water, which are limited in the apoplast and isoflavonoids that accumulate in plants during abiotic stress. In addition, several traits used by $X$. axonopodis pv. glycines to promote disease in soybean are related to those of symbiotic bacteria with this leguminous plant, suggesting that they experience a similar environment.

\section{MATERIALS AND METHODS}

Bacterial strains, plasmids, and recombinant techniques.

The bacterial strains and plasmids used in this study are described in Table 3. X. axonopodis pv. glycines 12-2 was cultured at $28^{\circ} \mathrm{C}$ in Luria Bertani (LB) agar (LA) for routine work or in the minimal medium M9 (Sambrook et al. 1989). Escherichia coli strains were routinely grown in LB medium at $37^{\circ} \mathrm{C}$. Bacterial growth was monitored by measuring the absorbance of cell suspensions at $600 \mathrm{~nm}$. Primers used in this work are listed in Supplementary Table S2. Antibiotics were added to media at the following concentrations (per milliliter): kanamycin, $50 \mu \mathrm{g}$; chephalexin, $50 \mu \mathrm{g}$; and gentamycin, $40 \mu \mathrm{g}$. All DNA manipulations, including DNA isolation, plasmid extraction, restriction digestion, ligation, and gel electrophoresis were performed as described previously (Sambrook et al. 1989).

\section{Inoculation and enumeration of bacteria in plants.}

Cell suspensions of $X$. axonopodis pv. glycines $\left(\mathrm{OD}_{600}=0.2\right.$; approximately $10^{8}$ cells per milliliter) in water containing $0.01 \%$ Silwet L-77 were vacuum infiltrated into soybean cv. Spencer (approximately 4 weeks old) and were incubated for 4 days under plant growth lights with a 12 -h photoperiod. Bacterial cells from infected soybean were then harvested in an acidic phenol RNA-stabilizing solution (Yu et al. 2013). Approximately 300 infected soybean leaves were cut into squares (approximately $3 \times$ $3 \mathrm{~mm}^{2}$ ) directly into $600 \mathrm{ml}$ of the RNA-stabilizing solution and were sonicated for $10 \mathrm{~min}$. The solution was then filtered through sterilized cheesecloth to remove the plant tissue. The filtrate was centrifuged at $11,295 \times g$ for $10 \mathrm{~min}$, and the pellet was suspended in $3 \mathrm{ml}$ of residual supernatant. The pellet suspension was filtered through a 5- $\mu \mathrm{m}$ filter. The bacterial cells were collected by centrifugation at $6,797 \times g$ for $10 \mathrm{~min}$, the residual supernatant was discarded and the pellets were flash frozen and stored at $-80^{\circ} \mathrm{C}$ until the RNA extraction process. Three biological replicates were performed.

\section{mRNA isolation, mRNA sequencing, and gene expression analysis.}

Sequencing was performed on mRNA isolated from $X$. axonopodis pv. glycines grown in planta and in M9 minimal medium. Total RNA was isolated with TRIzol (Invitrogen Life Technologies, Carlsbad, CA, U.S.A.), using the method of Santiago-Vazquez and associates (2006). Contaminating DNA

Table 3. Bacterial strains and plasmids used in this study

\begin{tabular}{|c|c|c|}
\hline Bacterial strain or plasmid & Relevant characteristic $^{\mathbf{a}}$ & Reference or source \\
\hline Xanthomonas axonopodis pv. glycines $12-2$ & Wild type, soybean pathogen & Thowthampitak et al. 2008 \\
\hline XagID2689 mutant & $\mathrm{Km}^{\mathrm{r}}$, XagID2689::Kan, $12-2$ derivative & This study \\
\hline XagID343 mutant & $\mathrm{Km}^{\mathrm{r}}$, XagID343::Kan, $12-2$ derivative & This study \\
\hline XagID1501 mutant & $\mathrm{Km}^{\mathrm{r}}$, XagID1501::Kan, 12-2 derivative & This study \\
\hline$m d c$ mutant & $\begin{array}{l}\mathrm{Km}^{\mathrm{r}} \text {, malonate decarboxylase operon }(m d c):: \mathrm{Kan}, X . \text { axonopodis pv. } \\
\text { glycines } 12-2 \text { derivative }\end{array}$ & This study \\
\hline phoU-pstSCAB mutant & $\mathrm{Km}^{\mathrm{r}}$, phoU-pstSCAB-::Kan, X. axonopodis pv. glycines $12-2$ derivative & This study \\
\hline \multicolumn{3}{|c|}{ 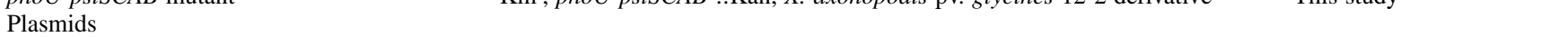 } \\
\hline pTok2 & ColE1 replicon, suicide plasmid, $\mathrm{Tc}^{\mathrm{r}}$ & Kitten and Willis 1996 \\
\hline pPROBE-KT & $\begin{array}{l}\text { Broad host-range plasmid with a transcriptional fusion cassette containing } \\
\text { a promoterless } g f p \text { reporter gene; } \mathrm{Km}^{\mathrm{r}}\end{array}$ & Miller et al. 2000 \\
\hline pKD13 & FRT-Km ${ }^{\mathrm{r}}$-FRT, oriR6K, $\mathrm{Ap}^{\mathrm{r}}, \mathrm{Km}^{\mathrm{r}}$ & Datsenko and Wanner 2000 \\
\hline pBBR1MCS-5 & Broad host-range cloning vector, $l a c Z, \mathrm{Gm}^{\mathrm{r}}$ & Kovach et al. 1995 \\
\hline pXag2689:GFP & XagID2689 promoter cloned with BamHI in pPROBE-KT & This study \\
\hline pXagmdc & $m d c$ operon with native promoter cloned into pBBR1MCS-5 $\mathrm{Gm}^{\mathrm{r}}$ & This study \\
\hline pTok $2:: \Delta$ XagID2689 & $\Delta$ XagID2689::Kan from overlapping PCR cloned into pTok2, $\mathrm{Tc}^{\mathrm{r}}, \mathrm{Km}^{\mathrm{r}}$ & This study \\
\hline pTok $2:: \Delta$ XagID343 & $\Delta$ XagID343::Kan from overlapping PCR cloned into pTok2, $\mathrm{Tc}^{\mathrm{r}}, \mathrm{Km}^{\mathrm{r}}$ & This study \\
\hline pTok $2:: \Delta$ XagID1501 & $\Delta$ XagID1501::Kan from overlapping PCR cloned into pTok2, $\mathrm{Tc}^{\mathrm{r}}, \mathrm{Km}^{\mathrm{r}}$ & This study \\
\hline pTok $2:: \Delta m d c$ & $\Delta m d c::$ Kan from overlapping PCR cloned into pTok2, $\mathrm{Tc}^{\mathrm{r}}, \mathrm{Km}^{\mathrm{r}}$ & This study \\
\hline pTok $2:: \Delta$ phoU-pstSCAB & AphoU-pstSCAB::Kan from overlapping PCR cloned into pTok2, $\mathrm{Tc}^{\mathrm{r}}, \mathrm{Km}^{\mathrm{r}}$ & This study \\
\hline
\end{tabular}

${ }^{\mathrm{a}} \mathrm{Km}^{\mathrm{r}}, \mathrm{Tc}^{\mathrm{r}}, \mathrm{Gm}^{\mathrm{r}}$, and $\mathrm{Ap}^{\mathrm{r}}$ indicate kanamycin, tetracycline, gentamycin, and ampicillin resistance, respectively; FRT = FLP recombination target. 
was removed using the Turbo DNA-free kit (Ambion, Austin, TX, U.S.A.). Because the total RNA of $X$. axonopodis pv. glycines in-planta samples was contaminated with plant ribosomal RNA, the eukaryotic ribosomal RNA was removed, using a Ribo-Zero rRNA removal kit for plant leaf (Epicentre, Madison, WI, U.S.A.). The ribosomal RNA of bacteria in planta samples was removed with a Ribo-Zero rRNA removal kit for gram-negative bacteria, according to the manufacturer's protocol. mRNA quality was assessed with a 2100 Bioanalzyer (Agilent, Santa Clara, CA, U.S.A.). Enriched mRNA samples were converted into cDNA, libraries were prepared and were sequenced on an Illumina HiSeq 2000 at the QB3-Functional Genomics Laboratory at the University of California, Berkeley. Three replicate samples were assigned distinct bar-coded linkers and were loaded onto one flow cell. All short reads of cDNA sequence were mapped to $X$. axonopodis pv. glycines 12-2 open reading frames using Bowtie 0.12.7 (Chatnaparat et al. 2012; Langmead et al. 2009). Differential gene expression was analyzed with edgeR, a Bioconductor package (Gentleman et al. 2004; Robinson et al. 2010).

\section{Total RNA isolation and qRT-PCR.}

Total RNA for qRT-PCR analysis was extracted using TRIzol (Invitrogen Life Technologies) and contaminated DNA was eliminated using the Turbo DNA-free kit (Ambion). RNA samples were analyzed for quality using a Bio Analyzer 2100 (Agilent). cDNA was generated from $1 \mu \mathrm{g}$ of RNA, using SuperScript II (Invitrogen Life Technologies) and random hexamers according to the manufacturer's instructions. To confirm that DNA was removed, samples processed in parallel without reverse transcription served as negative controls in qPCR experiments described below. qPCR was performed on $1 \mu \mathrm{g}$ of the cDNA, using LightCycler FastStart DNA MasterPLUS SYBR Green I (Roche, Indianapolis, IN, U.S.A.) on an Applied Biosystems 7300 Real-Time PCR System (Applied Biosystems, Foster City, CA, U.S.A.), following the manufacturer's specifications. Integration host factor A (ihfA) DNA was used as an endogenous control gene to normalize gene expression (Champoiseau et al. 2006). Melting curve analysis was used to verify amplification of a single product. The concentration of amplification products from negative controls (RNA samples to which no superscript was added) was undetectable in all cases, indicating a lack of interference from contaminating DNA.

\section{Generation of knockout mutants.}

Site-directed deletion of selected plant-inducible genes was accomplished using splice overlap extension mutagenesis (Heckman and Pease 2007). The upstream and downstream regions flanking target genes in $X$. axonopodis pv. glycines were amplified using primers unique to these regions, with one containing an extension complementary to a kanamycinresistance cassette flanked with FLP recombination target (FRT) sites from pKD13 (Datsenko and Wanner 2000). The two amplicons generated contained ends that overlapped those of the resistance cassette, which were then linked with the resistance cassette by overlap extension PCR. The final larger fragment was then cloned into the destination vector pTok2, using the quick ligation protocol (New England Biolabs, Inc., Beverly, MA, U.S.A.), and was introduced into the mobilizing strain Escherichia coli S17-1 by transformation and was then transferred to $X$. axonopodis pv. glycines via conjugation. The transformants were plated on LB plates containing kanamycin and cephalexin and the resulting mutants that were kanamycin resistant but tetracycline sensitive were selected. Gene disruption was confirmed using PCR, with primers specific to the sequence flanking each gene.

\section{Virulence and bacterial growth in soybean.}

The virulence of $X$. axonopodis pv. glycines strains was assessed on soybean cv. Spencer, following topical spray application (Kaewnum et al. 2005). Briefly, cell suspensions of a given strain $\left(\mathrm{OD}_{600}=0.2\right.$; approximately $10^{8}$ cells per milliliter) in $1 \mathrm{mM}$ buffer were sprayed onto leaves of plants (approximately 4 weeks old) maintained in a greenhouse (average temperature about $25^{\circ} \mathrm{C}$ ). At 7 to 10 days after inoculation, disease severity was assessed by counting the number of lesions on each leaf. Three trifoliate leaves, collected from each of the top, middle, and basal portions of three plants from each of five replicate pots, were evaluated for each strain. The experiments were repeated twice with similar results.

For bacterial growth in soybean, cells of a given strain were resuspended in $1 \mathrm{mM}$ buffer to a final density of approximately $10^{6}$ cells per milliliter and were infiltrated under vacuum into soybean plants (3 to 4 weeks old). Leaves were randomly collected from each plant at a given time point after infiltration (three leaves at each sample time for each strain). Samples were macerated in $5 \mathrm{ml}$ (final volume) of $0.1 \mathrm{M}$ potassium phosphate buffer, using a mortar and pestle. The number of viable cells was determined by dilution plating on LA amended with the appropriate antibiotics. Cell numbers were calculated after enumeration of colonies on plates incubated at $28^{\circ} \mathrm{C}$ for $48 \mathrm{~h}$. The experiments were repeated three times with similar results.

\section{Antimicrobial agent susceptibility tests.}

To measure the antimicrobial agent susceptibility of $X$. axonopodis pv. glycines strains, the MIC values of compounds were determined in LB medium by a twofold dilution assay. Microtiter plates (96 well), each containing $100 \mu \mathrm{l}$ of a twofold dilution series of an antimicrobial solution. Then, $100 \mu$ of a suspension of a $X$. axonopodis pv. glycines strain $\left(10^{8}\right.$ cells per milliliter) was added to each well and was incubated for $24 \mathrm{~h}$ at $28^{\circ} \mathrm{C}$. The MIC was determined by observing the lowest concentration of the antimicrobial in which bacterial growth was inhibited by at least $90 \%$. Growth of bacterial strains was examined at $\lambda=$ $600 \mathrm{~nm}$ using a Synergy 2 plate reader (BioTek, Winooski, VT, U.S.A.). All tests were done in triplicate.

\section{Promoter activity in vitro and in planta.}

The promoter-containing sequences upstream of XagID2689 were amplified from genomic DNA of $X$. axonopodis pv. glycines using primers 2689PRO-F and 2689PRO-R. Each amplicon was digested with BamHI (New England BioLabs), was purified using a QIAEX II gel extraction kit (Qiagen Inc., Hilden, Germany), and was cloned immediately $5^{\prime}$ to the promoterless GFP reporter gene in pPROBE-KT (Miller et al. 2000). The resulting plasmid, designated pXag2689:GFP, was introduced into $X$. axonopodis pv. glycines by electroporation with a Bio-Rad GenePulser X cell electroporation system (Hercules, CA, U.S.A.).

To assess responsiveness of the promoter of Xag2689 to antimicrobial compounds, $X$. axonopodis pv. glycines harboring pXag2689:GFP was grown in LB supplemented with different antimicrobial agents. GFP fluorescence intensity and the $\mathrm{OD}_{600}$ was determined after $24 \mathrm{~h}$ of incubation at $28^{\circ} \mathrm{C}$, using a Synergy 2 plate reader (BioTek). Relative fluorescence was determined by normalizing the arbitrary fluorescence units to optical density.

To test the promoter activity of XagID2689 in planta, a $X$. axonopodis pv. glycines strain containing pXag2689:GFP was inoculated at $10^{8} \mathrm{CFU}$ per milliliter in soybean cultivars Spencer and Williams 82 and in tomato. The GFP fluorescence of bacteria that dispersed from cut leaves at $48 \mathrm{~h}$ after inoculation was quantified by epifluorescence microscopy, as in other studies (Burch et al. 2013). 


\section{Malonate catabolism.}

Consumption of malonate by $X$. axonopodis pv. glycines was assessed by adding $100 \mu \mathrm{l}$ of a suspension $\left(\mathrm{OD}_{600}=0.2\right)$ of the wild-type strain or the $m d c$ mutant strain to $5 \mathrm{ml}$ of $\mathrm{M} 9$ minimal medium supplemented with a given carbon source, and the cell density was measured at $28^{\circ} \mathrm{C}$ for $24 \mathrm{~h}$.

\section{ACKNOWLEDGMENTS}

We thank A. Zemach, M. Ionescu, R. Scott, and K. Hockett for help in RNA sequencing and analysis. This research was supported by the Royal Golden Jubilee program of the Thailand Research Fund, Center for Advanced Studies for Tropical Natural Resources (CASTNaR) and Kasetsart University Research and Development Institute. The authors have no conflict of interest to declare.

\section{LITERATURE CITED}

An, J. H., Lee, H. Y., Ko, K. N., Kim, E.-S., and Kim, Y. S. 2002. Symbiotic effects of deltamatB Rhizobium leguminosarum bv. trifolii mutant on clovers. Mol. Cells 14:261-266.

Athinuwat, D., Prathuangwong, S., Cursino, L., and Burr, T. 2009. Xanthomonas axonopodis pv. glycines soybean cultivar virulence specificity is determined by avrBs3 homolog avrXg1. Phytopathology 99:996-1004.

Beattie, G. A. 2011. Water relations in the interaction of foliar bacterial pathogens with plants. Annu. Rev. Phytopathol. 49:533-555.

Beliën, T., Van Campenhout, S., Robben, J., and Volckaert, G. 2006. Microbial endoxylanases: Effective weapons to breach the plant cellwall barrier or, rather, triggers of plant defense systems? Mol. PlantMicrobe Interact. 19:1072-1081.

Boch, J., Joardar, V., Gao, L., Robertson, T. L., Lim, M., and Kunkel, B. N. 2002. Identification of Pseudomonas syringae pv. tomato genes induced during infection of Arabidopsis thaliana. Mol. Microbiol. 44: 73-88.

Boureau, T., Routtu, J., Roine, E., Taira, S., and Romantschuk, M. 2002. Localization of hrpA-induced Pseudomonas syringae pv. tomato DC3000 in infected tomato leaves. Mol. Plant Pathol. 3:451-460.

Brown, D. G., and Allen, C. 2004. Ralstonia solanacearum genes induced during growth in tomato: An inside view of bacterial wilt. Mol. Microbiol. 53:1641-1660.

Burch, A. Y., Finkel, O. M., Cho, J. K., Belkin, S., and Lindow, S. E. 2013. Diverse microhabitats experienced by Halomonas variabilis on saltsecreting leaves. Appl. Environ. Microbiol. 79:845-852.

Burse, A., Weingart, H., and Ullrich, M. S. 2004. The phytoalexin-inducible multidrug efflux pump AcrAB contributes to virulence in the fire blight pathogen, Erwinia amylovora. Mol. Plant-Microbe Interact.17: 43-54.

Büttner, D., and Bonas, U. 2010. Regulation and secretion of Xanthomonas virulence factors. FEMS Microbiol. Rev. 34:107-133.

Cavaliere, C., Cucci, F., Foglia, P., Guarino, C., Samperi, R., and Laganà, A. 2007. Flavonoid profile in soybeans by high-performance liquid chromatography/tandem mass spectrometry. Rapid Commun. Mass Spectrom. 21:2177-2187.

Champoiseau, P., Daugrois, J.-H., Pieretti, I., Cociancich, S., Royer, M., and Rott, P. 2006. High variation in pathogenicity of genetically closely related strains of Xanthomonas albilineans, the sugarcane leaf scald pathogen, in Guadeloupe. Phytopathology 96:1081-1091.

Chatnaparat, T., Prathuangwong, S., Ionescu, M., and Lindow, S. E. 2012. XagR, a LuxR homolog, contributes to the virulence of Xanthomonas axonopodis pv. glycines to soybean. Mol. Plant-Microbe Interact. 25: 1104-1117.

Chatterjee, S., Sankaranarayanan, R., and Sonti, R. V. 2003. PhyA, a secreted protein of Xanthomonas oryzae pv. oryzae, is required for optimum virulence and growth on phytic acid as a sole phosphate source. Mol. Plant-Microbe Interact. 16:973-982.

Chen, A.-M., Wang, Y.-B., Jie, S., Yu, A.-Y., Luo, L., Yu, G.-Q., Zhu, J.-B., and Wang, Y.-Z. 2010. Identification of a TRAP transporter for malonate transport and its expression regulated by GtrA from Sinorhizobium meliloti. Res. Microbiol. 161:556-564.

Chen, C., and Beattie, G. A. 2008. Pseudomonas syringae BetT is a lowaffinity choline transporter that is responsible for superior osmoprotection by choline over glycine betaine. J. Bacteriol. 190:2717-2725.

Chen, C., Li, S., McKeever, D. R., and Beattie, G. A. 2013. The widespread plant-colonizing bacterial species Pseudomonas syringae detects and exploits an extracellular pool of choline in hosts. Plant J. 75: 891-902.
Collmer, A., and Keen, N. T. 1986. The role of pectic enzymes in plant pathogenesis. Annu. Rev. Phytopathol. 24:383-409.

Crépin, S., Chekabab, S.-M., Le Bihan, G., Bertrand, N., Dozois, C. M., and Harel, J. 2011. The Pho regulon and the pathogenesis of Escherichia coli. Vet. Microbiol. 153:82-88.

Crépin, S., Lamarche, M. G., Garneau, P., Séguin, J., Proulx, J., Dozois, C. M., and Harel, J. 2008. Genome-wide transcriptional response of an avian pathogenic Escherichia coli (APEC) pst mutant. BMC Genomics 9:568.

Danhorn, T., Hentzer, M., Givskov, M., Parsek, M. R., and Fuqua, C. 2004. Phosphorus limitation enhances biofilm formation of the plant pathogen Agrobacterium tumefaciens through the PhoR-PhoB regulatory system. J. Bacteriol. 186:4492-4501.

Das, A., Rangaraj, N., and Sonti, R. V. 2009. Multiple adhesin-like functions of Xanthomonas oryzae pv. oryzae are involved in promoting leaf attachment, entry, and virulence on rice. Mol. Plant-Microbe Interact.22:73-85.

Datsenko, K. A., and Wanner, B. L. 2000. One-step inactivation of chromosomal genes in Escherichia coli $\mathrm{K}-12$ using PCR products. Proc. Natl. Acad. Sci. U.S.A. 97:6640-6645.

Déjean, G., Blanvillain-Baufumé, S., Boulanger, A., Darrasse, A., Dugé de Bernonville, T., Girard, A.-L., Carrére, S., Jamet, S., Zischek, C., Lautier, M., Solé, M., Büttner, D., Jacques, M.-A., Lauber, E., and Arlat, M. 2013. The xylan utilization system of the plant pathogen Xanthomonas campestris pv. campestris controls epiphytic life and reveals common features with oligotrophic bacteria and animal gut symbionts. New Phytol. 198:899-915.

Freeman, B. C., Chen, C., and Beattie, G. A. 2010. Identification of the trehalose biosynthetic loci of Pseudomonas syringae and their contribution to fitness in the phyllosphere. Environ. Microbiol. 12:1486-1497.

Gentleman, R. C., Carey, V. J., Bates, D. M., Bolstad, B., Dettling, M. Dudoit, S., Ellis, B., Gautier, L., Ge, Y., Gentry, J., Hornik, K., Hothorn, T., Huber, W., Iacus, S., Irizarry, R., Leisch, F., Li, C., Maechler, M., Rossini, A. J., Sawitzki, G., Smith, C., Smyth, G., Tierney, L., Yang, J. Y., and Zhang, J. 2004. Bioconductor: Open software development for computational biology and bioinformatics. Genome Biol. 5:R80.

Gottig, N., Garavaglia, B. S., Garofalo, C. G., Orellano, E. G., and Ottado, J. 2009. A filamentous hemagglutinin-like protein of Xanthomonas axonopodis pv. citri, the phytopathogen responsible for citrus canker, is involved in bacterial virulence. PLoS One 4:e4358.

Groth, D. E., and Braun, E. J. 1986. Growth kinetics and histopathology of Xanthomonas campestsris pv. glycines in leaves of resistant and susceptible soybeans. Phytopathology 76:959-965.

Guo, Y., Figueiredo, F., Jones, J., and Wang, N. 2011. HrpG and HrpX play global roles in coordinating different virulence traits of Xanthomonas axonopodis pv. citri. Mol. Plant-Microbe Interact. 24:649-661.

Heckman, K. L., and Pease, L. R. 2007. Gene splicing and mutagenesis by PCR-driven overlap extension. Nat. Protoc. 2:924-932.

Hockett, K. L., Burch, A. Y., and Lindow, S. E. 2013. Thermo-regulation of genes mediating motility and plant interactions in Pseudomonas syringae. PLoS One 8:e59850.

Hokawat, S., and Rudolph, K. 1993. The hosts of Xanthomonas. Page 4448 in: Xanthomonas. Swings, J. G., and Civerolo, E. L., eds. Chapman and Hall, London.

Jacobs, J. M., Babujee, L., Meng, F., Milling, A., and Allen, C. 2012. The in planta transcriptome of Ralstonia solanacearum: Conserved physiological and virulence strategies during bacterial wilt of tomato. MBio 3: e00114-12.

Jacobsen, S. M., Lane, M. C., Harro, J. M., Shirtliff, M. E., and Mobley, H. L. T. 2008. The high-affinity phosphate transporter Pst is a virulence factor for Proteus mirabilis during complicated urinary tract infection. FEMS (Fed. Eur. Microbiol. Soc.) Immunol. Med. Microbiol. 52:180-193.

Jones, S. B., and Fett, W. F. 1985. Fate of Xanthomonas campestris infiltrated into soybean leaves: An ultrastructural study. Phytopathology 75:733-741.

Kaewnum, S., Prathuangwong, S., and Burr, T. J. 2005. Aggressiveness of Xanthomonas axonopodis pv. glycines isolates to soybean and hypersensitivity responses by other plants. Plant Pathol. 54:409-415.

Kaewnum, S., Prathuangwong, S., and Burr, T. J. 2006. A pectate lyase homolog, xagP, in Xanthomonas axonopodis pv. glycines is associated with hypersensitive response induction on tobacco. Phytopathology 96 : 1230-1236.

Karunakaran, R., East, A. K., and Poole, P. S. 2013. Malonate catabolism does not drive N2 fixation in legume nodules. Appl. Environ. Microbiol. 79:4496-4498.

Kim, J.-G., Park, B. K., Yoo, C.-H., Jeon, E., Oh, J., and Hwang, I. 2003. Characterization of the Xanthomonas axonopodis pv. glycines Hrp pathogenicity island. J. Bacteriol. 185:3155-3166. 
Kitten, T., and Willis, D. K. 1996. Suppression of a sensor kinase-dependent phenotype in Pseudomonas syringae by ribosomal proteins L35 and L20. J. Bacteriol. 178:1548-1555.

Kovach, M. E., Elzer, P. H., Hill, D. S., Robertson, G. T., Farris, M. A., Roop, R. M., 2nd, and Peterson, K. M. 1995. Four new derivatives of the broad-host-range cloning vector pBBR1MCS, carrying different antibioticresistance cassettes. Gene 166:175-176.

Lamarche, M. G., Wanner, B. L., Crépin, S., and Harel, J. 2008. The phosphate regulon and bacterial virulence: A regulatory network connecting phosphate homeostasis and pathogenesis. FEMS (Fed. Eur. Microbiol. Soc.) Microbiol. Rev. 32:461-473.

Langmead, B., Trapnell, C., Pop, M., and Salzberg, S. L. 2009. Ultrafast and memory-efficient alignment of short DNA sequences to the human genome. Genome Biol. 10:R25.

Li, S., Yu, X., and Beattie, G. A. 2013. Glycine betaine catabolism contributes to Pseudomonas syringae tolerance to hyperosmotic stress by relieving betaine-mediated suppression of compatible solute synthesis. J. Bacteriol. 195:2415-2423.

Liu, H., Zhang, S., Schell, M. A., and Denny, T. P. 2005. Pyramiding unmarked deletions in Ralstonia solanacearum shows that secreted proteins in addition to plant cell-wall-degrading enzymes contribute to virulence. Mol. Plant-Microbe Interact. 18:1296-1305.

Liu, W., Yu, Y. H., Cao, S. Y., Niu, X. N., Jiang, W., Liu, G. F., Jiang, B. L., Tang, D. J., Lu, G. T., He, Y. Q., and Tang, J. L. 2013. Transcriptome profiling of Xanthomonas campestris pv. campestris grown in minimal medium MMX and rich medium NYG. Res. Microbiol. 164 466-479.

Lu, J., and Holmgren, A. 2014. The thioredoxin antioxidant system. Free Radic. Biol. Med. 66:75-87.

Maggiorani Valecillos, A., Rodríguez Palenzuela, P., and López-Solanilla, E. 2006. The role of several multidrug resistance systems in Erwinia chrysanthemi pathogenesis. Mol. Plant-Microbe Interact. 19:607-613.

Marco, M. L., Legac, J., and Lindow, S. E. 2005. Pseudomonas syringae genes induced during colonization of leaf surfaces. Environ. Microbiol. 7:1379-1391.

Martinez, J. L., Sánchez, M. B., Martínez-Solano, L., Hernandez, A., Garmendia, L., Fajardo, A., and Alvarez-Ortega, C. 2009. Functional role of bacterial multidrug efflux pumps in microbial natural ecosystems. FEMS (Fed. Eur. Microbiol. Soc.) Microbiol. Rev. 33:430-449.

Miller, W. G., Leveau, J. H. J., and Lindow, S. E. 2000. Improved $g f p$ and inaZ broad-host-range promoter-probe vectors. Mol. Plant-Microbe Interact. 13:1243-1250

Moreira, L. M., Facincani, A. P., Ferreira, C. B., Ferreira, R. M., Ferro, M. I. T., Gozzo, F. C., de Oliveira, J. C. F., Ferro, J. A., and Soares, M. R. 2015. Chemotactic signal transduction and phosphate metabolism as adaptive strategies during citrus canker induction by Xanthomonas citri. Funct. Integr. Genomics 15:197-210.

Osbourn, A. E., Barber, C. E., and Daniels, M. J. 1987. Identification of plant-induced genes of the bacterial pathogen Xanthomonas campestris pathovar campestris using a promoter-probe plasmid. EMBO J. 6:23-28.

Palumbo, J. D., Kado, C. I., and Phillips, D. A. 1998. An isoflavonoidinducible efflux pump in Agrobacterium tumefaciens is involved in competitive colonization of roots. J. Bacteriol. 180:3107-3113.

Piddock, L. J. V. 2006. Multidrug-resistance efflux pumps-Not just for resistance. Nat. Rev. Microbiol. 4:629-636.

Pletzer, D., and Weingart, H. 2014a. Characterization and regulation of the resistance-nodulation-cell division-type multidrug efflux pumps MdtABC and MdtUVW from the fire blight pathogen Erwinia amylovora. BMC Microbiol. 14:185.

Pletzer, D., and Weingart, H. 2014b. Characterization of AcrD, a resistancenodulation-cell division-type multidrug efflux pump from the fire blight pathogen Erwinia amylovora. BMC Microbiol. 14:13.

Pratt, J. T., Ismail, A. M., and Camilli, A. 2010. PhoB regulates both environmental and virulence gene expression in Vibrio cholerae. Mol. Microbiol. 77:1595-1605.

Rajeshwari, R., Jha, G., and Sonti, R. V. 2005. Role of an in planta-expressed xylanase of Xanthomonas oryzae pv. oryzae in promoting virulence on rice. Mol. Plant-Microbe Interact. 18:830-837.

Ravirala, R. S., Barabote, R. D., Wheeler, D. M., Reverchon, S., Tatum, O., Malouf, J., Liu, H., Pritchard, L., Hedley, P. E., Birch, P. R. J., Toth, I. K. Payton, P., and San Francisco, M. J. D. 2007. Efflux pump gene expression in Erwinia chrysanthemi is induced by exposure to phenolic acids. Mol. Plant-Microbe Interact. 20:313-320.

Ray, S. K., Rajeshwari, R., Sharma, Y., and Sonti, R. V. 2002. A highmolecular-weight outer membrane protein of Xanthomonas oryzae pv. oryzae exhibits similarity to non-fimbrial adhesins of animal pathogenic bacteria and is required for optimum virulence. Mol. Microbiol. 46: 637-647.
Robinson, M. D., McCarthy, D. J., and Smyth, G. K. 2010. edgeR: A Bioconductor package for differential expression analysis of digital gene expression data. Bioinformatics 26:139-140.

Rossier, O., Wengelnik, K., Hahn, K., and Bonas, U. 1999. The Xanthomonas Hrp type III system secretes proteins from plant and mammalian bacterial pathogens. Proc. Natl. Acad. Sci. U.S.A. 96: 9368-9373.

Ryan, R. P., Vorhölter, F.-J., Potnis, N., Jones, J. B., Van Sluys, M.-A., Bogdanove, A. J., and Dow, J. M. 2011. Pathogenomics of Xanthomonas: Understanding bacterium-plant interactions. Nat. Rev. Microbiol. 9: 344-355.

Sambrook, J., Fritsch, E. F., and Maniatis, T. 1989. Molecular Cloning: A Laboratory Manual, 2nd Ed. Cold Spring Harbor Laboratory Press, Cold Spring Harbor, NY, U.S.A..

Santiago-Vazquez, L. Z., Ranzer, L. K., and Kerr, R. G. 2006. Comparison of two total RNA extraction protocols using the marine gorgonian coral Pseudopterogorgia elisabethae and its symbiont Symbiodinium sp. Electron. J. Biotechnol. 9:598-603.

Santos, C. R., Hoffmam, Z. B., de Matos Martins, V. P., Zanphorlin, L. M., de Paula Assis, L. H., Honorato, R. V., Lopes de Oliveira, P. S., Ruller, R., and Murakami, M. T. 2014. Molecular mechanisms associated with xylan degradation by Xanthomonas plant pathogens. J. Biol. Chem. 289: 32186-32200.

Schacht, T., Unger, C., Pich, A., and Wydra, K. 2011. Endo- and exopolygalacturonases of Ralstonia solanacearum are inhibited by polygalacturonase-inhibiting protein (PGIP) activity in tomato stem extracts. Plant Physiol. Biochem. 49:377-387.

Slimestad, R., Fossen, T., and Verheul, M. J. 2008. The flavonoids of tomatoes. J. Agric. Food Chem. 56:2436-2441.

Solé, M., Scheibner, F., Hoffmeister, A.-K., Hartmann, N., Hause, G., Rother, A., Jordan, M., Lautier, M., Arlat, M., and Büttner, D. 2015. Xanthomonas campestris pv. vesicatoria secretes proteases and xylanases via the Xps type II secretion system and outer membrane vesicles. J. Bacteriol. 197:2879-2893.

Soto-Suárez, M., Bernal, D., González, C., Szurek, B., Guyot, R., Tohme, J., and Verdier, V. 2010. In planta gene expression analysis of Xanthomonas oryzae pathovar oryzae, African strain MAI1. BMC Microbiol. 10:170.

Stoitsova, S. O., Braun, Y., Ullrich, M. S., and Weingart, H. 2008 Characterization of the RND-type multidrug efflux pump MexAB-OprM of the plant pathogen Pseudomonas syringae. Appl. Environ. Microbiol. 74:3387-3393.

Stumpf, D. K., and Burris, R. H. 1981. Organic acid contents of soybean: Age and source of nitrogen. Plant Physiol. 68:989-991.

Sun, Q. H., Hu, J., Huang, G. X., Ge, C., Fang, R. X., and He, C. Z. 2005. Type-II secretion pathway structural gene xpsE, xylanase- and cellulase secretion and virulence in Xanthomonas oryzae pv. oryzae. Plant Pathol. 54:15-21.

Szczesny, R., Jordan, M., Schramm, C., Schulz, S., Cogez, V., Bonas, U., and Büttner, D. 2010. Functional characterization of the Xcs and Xps type II secretion systems from the plant pathogenic bacterium Xanthomonas campestris pv. vesicatoria. New Phytol. 187: 983-1002.

Tamir-Ariel, D., Navon, N., and Burdman, S. 2007. Identification of genes in Xanthomonas campestris pv. vesicatoria induced during its interaction with tomato. J. Bacteriol. 189:6359-6371.

Thowthampitak, J., Shaffer, B. T., Prathuangwong, S., and Loper, J. E. 2008. Role of $r p f F$ in virulence and exoenzyme production of Xanthomonas axonopodis pv. glycines, the causal agent of bacterial pustule of soybean. Phytopathology 98:1252-1260.

Tukey, H. B. 1970. The leaching of substances from plants. Annu. Rev. Plant Physiol. 21:305-324.

Vargas, P., Felipe, A., Michán, C., and Gallegos, M.-T. 2011. Induction of Pseudomonas syringae pv. tomato DC3000 MexAB-OprM multidrug efflux pump by flavonoids is mediated by the repressor PmeR. Mol. Plant-Microbe Interact. 24:1207-1219.

Wang, L., Rong, W., and He, C. 2008. Two Xanthomonas extracellular polygalacturonases, PghAxc and $\mathrm{PghBxc}$, are regulated by type III secretion regulators $\mathrm{HrpX}$ and $\mathrm{HrpG}$ and are required for virulence. Mol. Plant-Microbe Interact. 21:555-563.

Wengelnik, K., Rossier, O., and Bonas, U. 1999. Mutations in the regulatory gene hrpG of Xanthomonas campestris pv. vesicatoria result in constitutive expression of all hrp genes. J. Bacteriol. 181: 6828-6831.

Xu, J., Kim, J., Danhorn, T., Merritt, P. M., and Fuqua, C. 2012. Phosphorus limitation increases attachment in Agrobacterium tumefaciens and reveals a conditional functional redundancy in adhesin biosynthesis. Res. Microbiol. 163:674-684. 
Yang, S., Perna, N. T., Cooksey, D. A., Okinaka, Y., Lindow, S. E., Ibekwe, A. M., Keen, N. T., and Yang, C.-H. 2004. Genome-wide identification of plant-upregulated genes of Erwinia chrysanthemi 3937 using a GFP-based IVET leaf array. Mol. Plant-Microbe Interact. 17:999-1008.

Yu, X., Lund, S. P., Scott, R. A., Greenwald, J. W., Records, A. H., Nettleton, D., Lindow, S. E., Gross, D. C., and Beattie, G. A. 2013. Transcriptional responses of Pseudomonas syringae to growth in epiphytic versus apoplastic leaf sites. Proc. Natl. Acad. Sci. U.S.A. 110:E425-E434.
Zhang, Y., Callaway, E. M., Jones, J. B., and Wilson, M. 2009. Visualisation of hrp gene expression in Xanthomonas euvesicatoria in the tomato phyllosphere. Eur. J. Plant Pathol. 124:379-390.

Zhao, Y., Blumer, S. E., and Sundin, G. W. 2005. Identification of Erwinia amylovora genes induced during infection of immature pear tissue. J. Bacteriol. 187:8088-8103.

Zuluaga, A. P., Puigvert, M., and Valls, M. 2013. Novel plant inputs influencing Ralstonia solanacearum during infection. Front. Microbiol. 4:349. 